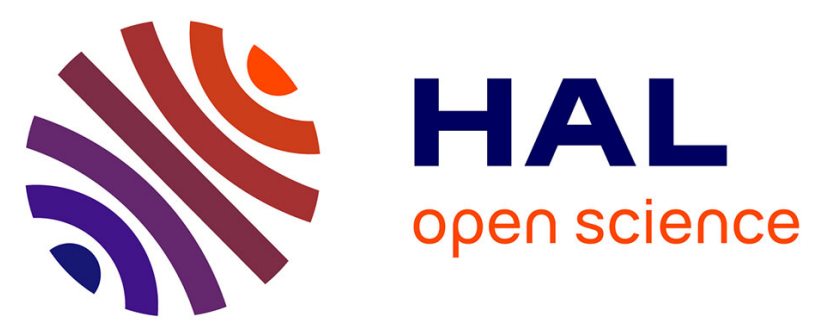

\title{
Prenatal exposure to pesticides and risk of preeclampsia among pregnant women: Results from the ELFE cohort
}

Isabelle Enderle, Nathalie Costet, Noriane Cognez, Cécile Zaros, Julien

Caudeville, Ronan Garlantézec, Cécile Chevrier, Alexandre Nougadere, Blandine de Lauzon-Guillain, Maela Le Lous, et al.

\section{To cite this version:}

Isabelle Enderle, Nathalie Costet, Noriane Cognez, Cécile Zaros, Julien Caudeville, et al.. Prenatal exposure to pesticides and risk of preeclampsia among pregnant women: Results from the ELFE cohort. Environmental Research, 2021, 197, pp.111048. 10.1016/j.envres.2021.111048 . hal-03217204

\author{
HAL Id: hal-03217204 \\ https://hal.science/hal-03217204
}

Submitted on 5 May 2021

HAL is a multi-disciplinary open access archive for the deposit and dissemination of scientific research documents, whether they are published or not. The documents may come from teaching and research institutions in France or abroad, or from public or private research centers.
L'archive ouverte pluridisciplinaire HAL, est destinée au dépôt et à la diffusion de documents scientifiques de niveau recherche, publiés ou non, émanant des établissements d'enseignement et de recherche français ou étrangers, des laboratoires publics ou privés. 


\section{Prenatal Exposure to Pesticides and Risk of Preeclampsia among Pregnant Women: Results from the ELFE Cohort}

Isabelle ENDERLE ${ }^{1,2}$, Nathalie COSTET $^{3}$, Noriane COGNEZ ${ }^{3}$, Cécile ZAROS $^{4}$, Julien

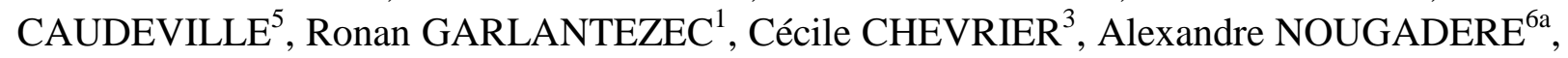
Blandine DE LAUZON-GUILLAIN ${ }^{7}$, Maela LE LOUS ${ }^{2}$, Rémi BERANGER ${ }^{1.2}$

1 CHU Rennes, Univ Rennes, Inserm, EHESP, Irset (Institut de recherche en santé, environnement et travail) - UMR_S 1085, F-35000 Rennes, France

2 Department of Obstetrics and Gynecology and Reproductive Medicine, Anne de Bretagne University Hospital, Rennes, France

3 Univ Rennes, Inserm, EHESP, Irset - UMR_S 1085, F-35000 Rennes, France

4 French Institute for Demographic Studies (Ined), French Institute for Medical Research and Health (Inserm), French Blood Agency, ELFE Joint Unit, F-75020 Paris, France

5 INERIS (French National Institute for Industrial Environment and Risks), 60550 Verneuil-en-Halatte, France

6 ANSES, Risk Assessment Department, 14 Rue Pierre et Marie Curie, F-94701 Maisons-Alfort, France 7 Université de Paris, CRESS, INSERM, INRAE, F-75004 Paris, France.

\footnotetext{
${ }^{\text {a }}$ Currently EFSA, Parma, Italy

Corresponding Autor:

Isabelle ENDERLE

Isabelle.enderle@chu-rennes.fr

CHU Rennes

16 Boulevard de Bulgarie

35200 RENNES

+33299265938
}

The authors declare that they have no competing interests. 
- The corresponding author is responsible for ensuring that the descriptions are accurate and agreed by all authors.

- Authors may have contributed in multiple roles 


\section{Abstract}

Background: Preeclampsia is a pregnancy-specific syndrome caused by abnormal placentation. Although environmental chemicals, including some pesticides, are suspected of impairing placentation and promoting preeclampsia, its relationship with preeclampsia has been insufficiently explored.

Objectives: We aimed to investigate the relation between non-occupational exposure to pesticides during pregnancy and the risk of preeclampsia.

Methods: The study cohort comprised 195 women with and 17,181 without preeclampsia from the ELFE birth cohort. We used toxicogenomic approaches to select 41 pesticides of interest for their possible influence on preeclampsia. We assessed household pesticide use (self-reported data), environmental exposure to agricultural pesticides (geographic information systems), and dietary exposure (food-frequency questionnaire with data from monitoring pesticide residues in food and water). Dietary exposures to pesticides were grouped into clusters of similar exposures to resolve collinearity issues. For each exposure source, pesticides were mutually adjusted, and odds ratios estimated with logistic regression models.

Results: The quantity of prochloraz applied within a kilometer of the women's homes was higher in women with than without preeclampsia (fourth quartile vs. others; adjusted odds ratio $[\mathrm{aOR}]=1.54$; 95\%CI: 1.02, 2.35), especially when preeclampsia was diagnosed before 34 weeks of gestation (aOR=2.25; 95\%CI: 1.01, 5.06). The reverse was observed with nearby cypermethrin application (aOR=0.59, 95\%CI: 0.36, 0.96). In sensitivity analyses, women with preeclampsia receiving antihypertensive treatment had a significantly higher probability of using herbicides at home during pregnancy than women without preeclampsia $(\mathrm{aOR}=2.20 ; 95 \% \mathrm{CI}: 1.23,3.93)$. No statistically significant association was found between dietary exposure to pesticide residues and preeclampsia.

Discussion: While the most of the associations examined remained statistically non-significant, our results suggest the possible influence on preeclampsia of residential exposures to prochloraz and some herbicides. These estimations are supported by toxicological and mechanistic data.

Keywords: Pesticides, Preeclampsia, Toxicogenetics, Geographic Information Systems, Food monitoring 
The ELFE survey is a joint project between the French Institute for Demographic Studies (INED) and the National Institute of Health and Medical Research (INSERM), in partnership with the French blood transfusion service (Etablissement français du sang, EFS), Santé publique France, the National Institute for Statistics and Economic Studies (INSEE), the Direction générale de la santé (DGS, part of the Ministry of Health and Social Affairs), the Direction générale de la prévention des risques (DGPR, Ministry for the Environment), the Direction de la recherche, des études, de l'évaluation et des statistiques (DREES, Ministry of Health and Social Affairs), the Département des études, de la prospective et des statistiques (DEPS, Ministry of Culture), and the Caisse nationale des allocations familiales (CNAF), with the support of the Ministry of Higher Education and Research and the Institut national de la jeunesse et de l'éducation populaire (INJEP). Via the RECONAI platform, it receives a government grant managed by the National Research Agency under the "Investissements d'avenir" programme (ANR-11-EQPX-0038). 


\section{Introduction}

Preeclampsia is defined by the onset of arterial hypertension (systolic blood pressure $>140 \mathrm{mmHg}$ or diastolic blood pressure $>90 \mathrm{mmHg}$ ) after 20 weeks of gestation in association with one of the following symptoms: proteinuria (>300 mg/day), acute kidney injury, liver dysfunction, neurological features, hemolysis, thrombocytopenia, or fetal growth restriction (Brown et al. 2018; Mol et al. 2016; Ramos et al. 2017). Early preeclampsia occurs before the end of the 34th week of gestation, in contrast to late preeclampsia, which occurs later on (Mayrink et al. 2018).

Preeclampsia affects 3-5\% of pregnancies (Abalos et al. 2013; Mol et al. 2016; Ramos et al. 2017a), causing more than 500,000 fetal and neonatal deaths and more than 70,000 maternal deaths per year in the world (Brown et al. 2018). In 2016 in France, it complicated 2\% of pregnancies (Enquête nationale périnatale Rapport 2016). It is the second leading cause of maternal morbidity and mortality worldwide (Mayrink et al. 2018). Women with severe preeclampsia can present several complications, including neurologic injuries, HELLP syndrome (Hemolysis, Elevated Liver enzymes, Low Platelet count), disseminated intravascular coagulation, hepatic hematoma or rupture, acute kidney failure, pulmonary edema, and placental abruption (Brown et al. 2018; Mol et al. 2016; Ramos et al. 2017a). Fetal complications include growth restriction, stillbirth, neonatal death, and prematurity-associated complications from early delivery (Mol et al. 2016).

The literature has identified several personal risk factors for preeclampsia: individual or familial history of preeclampsia, chronic or gestational hypertension, chronic kidney disease, autoimmune diseases (e.g., systemic lupus erythematosus, antiphospholipid antibody syndrome), diabetes type 1 or 2 , nulliparity, age $\geq 40$ years, body mass index greater than $35 \mathrm{~kg} / \mathrm{m}^{2}$, and multiple pregnancy (Mayrink et al. 2018; Mol et al. 2016; Ramos et al. 2017a). Although its pathophysiology has not yet been fully elucidated, other studies had demonstrated that preeclampsia results from abnormal placentation, maternal inflammatory response and disruption of circulating angiogenic balance (Lecarpentier and Tsatsaris 2016; Mayrink et al. 2018; Ramos et al. 2017a). The most important angiogenic factors involved in preeclampsia are soluble Fms-like tyrosine kinase 1 (sFlt-1) and placental growth factor (PIGF) (Lecarpentier and Tsatsaris 2016). Prospective longitudinal studies have demonstrated that women who develop preeclampsia have higher circulating levels of sFlt-1 and lower circulating levels of PIGF than women who do not (Lecarpentier and Tsatsaris 2016).

Epidemiologic studies have also proposed and explored the role of environmental exposures in the onset of preeclampsia (Kahn and Trasande 2018). Several studies of ambient air pollution have suggested higher risks of hypertensive disorders in pregnancy (Dadvand et al. 2014; Pedersen et al. 2014, 2017) and thus a potential environmental origin for some forms of preeclampsia. Only a few researchers, however, have focused on the possible role of pesticide exposure, and their findings remained limited and discordant. Two large studies reported a higher risk of preeclampsia among women occupationally 
or domestically (pesticide use in the garden or house) exposed to pesticides (Ledda et al. 2015; Saldana et al. 2009). Both, however, used self-reported exposure information. Inversely, two studies using serum or urinary biomarkers to assess organochlorine or organophosphate pesticide exposure found no associations with the risk of preeclampsia (Smarr et al. 2016; Warembourg et al. 2019), but both had small sample sizes, and Smarr et al. used only preconceptional biological samples. Although these potential associations between preeclampsia and pesticides have not been fully explained, several mechanisms have been suggested for organophosphorus or triazole pesticides, including induction of apoptosis and impairment of the expression of key regulatory genes involved in the invasion and migration of trophoblast cells (Yang et al. 2019; Zhou et al. 2016).

In animal studies, Levario-Carrillo et al. observed signs of degeneration, vascular congestion, areas of fibrosis, and hemorrhages on the placentas of pregnant rats orally exposed to methyl parathion (LevarioCarrillo et al. 2004). Using in vitro and ex vivo exposure models to evaluate the effects on the human placenta of chlorpyrifos, one of the most widely used organophosphate insecticides, Ridano et al. found that this exposure increased stroma cell apoptosis, impaired intravillous matrix composition, basement membrane thickness, and trophoblastic layer integrity (Ridano et al. 2017). Because the changes observed resembled those described in conditions associated with increased placental oxidative stress, such as preeclampsia and intrauterine growth restriction, they hypothesized that reactive oxygen species induced by chlorpyrifos trigger tissue damage.

Pesticides are widely used in agriculture (EFSA 2020), but also in household settings, in human and veterinary medicine, for vector control, and to treat construction materials (ANSES 2010; European Commission 2020; Mostafalou and Abdollahi 2017). This massive usage contaminates the environment, exposing the general population, including pregnant women, to pesticides (Dereumeaux et al. 2016; Haines et al. 2017; Osaka et al. 2016; Ramos et al. 2017b). With about 80,000 tons of pesticides sold for agricultural use in 2018, France is one of the three largest users in Europe (Eurostat 2020). Exposure of pregnant women comes from different sources, including occupational or domestic usage, diet, pesticide drift from treated areas, and ambient air or water pollution (ANSES 2010). Diet is frequently assumed to be the main source of their pesticide exposure (de Gavelle et al. 2016), although this may vary between pesticide active substances, the studied populations and geographic areas. Analysis of 140 pesticides and their metabolites in hair strands of 311 pregnant women from the French ELFE birth cohort detected a median of 43 chemicals per woman (Béranger et al. 2018).

Using data from a large sample of women from the ELFE cohort, with complementary information on their environmental pesticide exposure (domestic pesticide use, residential proximity to agricultural pesticide application, and dietary exposure to pesticides), we aimed to assess the influence of exposure to several pesticides of interest on the risk of preeclampsia in pregnant women. 


\section{Materials and Methods}

\section{Study design}

ELFE ("Etude Longitudinale Française depuis l'Enfance") is a French nationwide birth cohort intended to explore the influence of the environmental and socioeconomic context on children's health and development from birth to the age of 20 years. The ELFE cohort has previously been described in detail (Charles et al. 2019).

Overall, 349 maternity departments were randomly selected among the 544 in mainland France with more than one delivery per day. Women aged 18 years or older who gave birth in those departments to liveborn singletons or twins after 33 weeks of gestation were included in the study if they were able to and did consent to participate and did not plan to leave mainland France in the 3 years following the birth. More than $96 \%$ of the mothers who met the first two inclusion criteria $(n=37,494)$ were contacted by research assistants during their stay in the maternity unit, and $51 \%$ agreed to participate in the cohort. Women were enrolled during four inclusion periods in 2011, to enable seasonal variability to be considered: from April 1 to 4, June 27 to July 4, September 27 to October 4, and November 28 to December 5.

Because insulin resistance is hypothesized to contribute to the pathophysiology of preeclampsia, (Weissgerber and Mudd 2015), women with diabetes were excluded from the study (type 1 or 2; $\mathrm{n}=164)$. We excluded among the 18,040 participating mothers those with chronic hypertension $(\mathrm{n}=$ 177), as well as those with gestational hypertension $(n=351)$, which involves pathophysiological mechanisms different from those for isolated preeclampsia (Figure 1). Since occupational pesticide exposure was not enough common to be studied, we also excluded farmers $(n=57)$ to minimize the number of occupationally exposed women in our population. In accordance with the definition of the French society of arterial hypertension and the French college of gynecologists and obstetricians (Collège National des Gynécologues et Obstétriciens Français 2015), we defined preeclampsia as the onset of arterial hypertension (systolic blood pressure $>140 \mathrm{mmHg}$ or diastolic blood pressure $>90$ $\mathrm{mmHg}$ ) after 20 weeks of gestation along with proteinuria (>300 mg/day). Our study population finally included 195 women with preeclampsia and 17,181 women with no hypertensive disease.

\section{Data collection}

Trained midwives enrolled women at birth, before their discharge from the maternity ward, and collected their sociodemographic, socioeconomic and medical characteristics in face-to-face interviews. Data about the pregnancy, delivery, and medical history were also collected from medical records, and women completed a self-administered food-frequency questionnaire about their habitual food intake in the 3 months before giving birth. Two months after childbirth, parents were asked in telephone 
interviews to respond to questionnaires about social and medical data and household pesticide use over the previous 12 months. In all, $78 \%$ of the families answered the questions about pesticides (Figure 1). More details are available on two websites: https://www.elfe-france.fr/en and https://pandora.vjf.inserm.fr/public/index.php.

\section{Selection of pesticides of interest}

A toxicogenomic approach using the Comparative Toxicogenomics Database (CTD), (http://ctdbase.org/) was used to select pesticides of interest. This database presents scientifically reviewed and curated information on chemicals, relevant genes and proteins, and their interactions in vertebrates and invertebrates. It integrates information about sequences, reference articles, species, microarrays, and general toxicology to provide a unique centralized resource for toxicogenomic research (Mattingly et al. 2003, 2006). We first searched for genes up- or down-regulated in preeclampsia and then for all pesticides interacting with these genes (data updated in July 2020) (see further details in Table S1). We also selected pesticides previously associated with preeclampsia and other hypertensive disorders of pregnancy in the literature (see Table S2). Combining these two approaches, we selected 41 active substances of interest.

\section{Exposure assessment - household pesticide use}

Two months after childbirth, a telephone interview collected self-reported information about 13 types of domestic pesticide uses in the previous 12 months ( $\mathrm{n}=13,578$ families): insecticides against crawling insects, insecticides against flying insects, herbicide use on weeds, insecticides against fleas and ticks (flea collars; pesticides other than flea collars), insecticides for outdoor plants, fungicides for outdoor plants, fungicides and insecticides for inside plants, slug pellets, wood preservative, and pesticides against moss and lichen. Then, the lists of pesticide active substances per type of uses were extracted from a complete report on the sources of exposure to pesticides in the French general population (ANSES 2010). According to this report, five of these types of household use may involve pesticides of interest: those used against crawling insects, herbicides, flea collars, pesticides against fleas and ticks other than flea collars, and fungicides used on outdoor plants. These types of pesticide use were employed as a proxy for exposure to 14 active substances of interest (Table 1). These data were used as binary variables (used/not used).

\section{Exposure assessment - residential proximity to agricultural pesticide applications}

For women with available addresses $(n=16,000)$, residential location at delivery was geocoded by the French National Institute of Statistics and Economic Studies (INSEE) based on national databases 
(Directorate of Taxes, French Post Office, municipalities). Using a geographic information systems (GIS), we estimated the total acreage of 28 types of crops within a 1,000-meter distance around each home. Land use information was obtained from the graphic parcel registry for 2011 (GPR; 1:5,000). For vineyards and orchards, land use information was complemented with the vegetation layer of the $\mathrm{BD}$ Topo ${ }^{\circledR}$ (French National Institute of Geographic and Forest, IGN; 1:5,000) and the Corine Land Cover database for 2006 (CLC; SoeS, 2006; 1:100,000). Crops identified as vineyards or orchards in both the BD Topo ${ }^{\circledR}$ and CLC were added to the GPR layer. Geographical data were processed with ArcGIS 10.3 (ESRI, Redlands, CA).

Since 2014, the BNV-D (French national databank of phytopharmaceutical sales by distributors) has been collecting the annual quantities of pesticides purchased in mainland France at the postal code level (Le Gall et al. 2013). The database enabled the identification of data for sales specifically to farmers. Agricultural practices for 2014 (i.e., possible correspondence between pesticides and the different crop types available in the GPR) were defined by expert assessment, taking into account both local agronomic practices and regulatory data (French National Institute of Agronomic Research). Combining sales data with a spatial disaggregation method based on agricultural practices (French national institute for industrial environment and risks, INRAE; French national institute for industrial environment and risks, INERIS) and land use information, we estimated the average density ( $\mathrm{kg} /$ hectare [ha]) of active substances applied to each of the 24 crop types in 2014. Since the quantity of pesticides purchased was attributed to the postal code of the farmer's residence (or the head office of his/her company), which could differ from the location of the crops, we averaged densities of active substances at the district level to limit the risk of overestimating exposure. The recommended doses for agricultural applications of pesticides in 2011 were used to ensure the plausibility of the estimated densities (Couteux and Lejeune 2010). Because too low an average density for any type of pesticide would indicate minimal frequency of its usage in the district, estimated densities less than $10 \%$ of the minimum recommended doses were converted to zero. Similarly, to correct likely outliers, densities more than 10 times the maximum recommended dose were shrunk to this threshold.

No major changes occurred between 2011 and 2014 in France in agricultural practice and agricultural pesticide usage. The quantity of agricultural pesticides applied within 1,000 meters of a residential location was estimated by multiplying each crop acreage in 2011 by the corresponding density of the active substance applied in the corresponding district in 2014. Data were available for 87 active substances (referred to as "pesticides" for the rest of the document), including 16 of the 41 pesticides of interest.

The choice of the buffer size (1,000 meters) was made a priori, based on filed experimentation conducted in France in 2012 (Béranger 2014a; see Chapter 3). 


\section{Exposure assessment - dietary exposure to pesticide residues}

De Gavelle et al. (2016) assessed the maternal daily dietary exposure to 317 pesticides and metabolites for 14,099 women ( $78 \%$ of the population) from the ELFE cohort, by combining individual food consumption levels with mean pesticide concentrations in food. Briefly, food consumption frequencies and portion sizes had been collected at birth with a validated self-administered food-frequency questionnaire focusing on the last 3 months of pregnancy (Deschamps et al. 2009). The concentration levels came from the second French Total Diet Study (TDS2), complemented by the 2011 national monitoring results of pesticide residues in food and drinking water and the 2011 infant Total Diet Study (iTDS) including 90 common foods for adults (ANSES 2014; Nougadère et al. 2012, 2020).

We used these individual dietary exposures from the lower-bound scenario (LB) to calculate the median and the $75^{\text {th }}$ percentile (P75) of exposure in our studied population and for 29 pesticides with non-null exposure (Table S4) out of the 41 pesticides of interest. Under this LB scenario, considered more realistic for agricultural pesticides, analytical results below the limit of detection (LOD) were converted to zero, and unquantifiable (but detected) results (between the LOD and the limit of quantification (LOQ)) were set to the LOD (de Gavelle et al. 2016).

\section{Categorizing the exposure}

The quantity of agricultural pesticides applied near households (within a 1,000-m perimeter) and estimated dietary exposure to pesticides were both asymmetrically distributed. Exposure variables were categorized as follows: the first three quartiles versus the fourth. The threshold value for categorization (P75 of exposure) is reported in the Table S3-S4. For a given pesticide, the women with an estimated exposure lower than the P75 were considered non-exposed, and the ones with an estimated exposure equal to P75 or higher were considered exposed. When the proportion of exposed women was less than $25 \%$, we categorized the exposure variables as exposed or unexposed (agricultural pesticide applications; Table S3).

\section{Statistical analysis}

\subsection{Covariate selection}

Covariate selection was based on directed acyclic graph (DAG) approach (Shrier and Platt 2008). An a priori model of the postulated relations between the pesticide exposures, preeclampsia, and the covariates was constructed (Shrier and Platt 2008), enabling theoretically and expert-based adjustment sets of covariates. We chose the most parsimonious model to limit overadjustment and maximize statistical power (see Figure S1). 
All models were adjusted for maternal age (continuous), body mass index (BMI; BMI $<18.5 \mathrm{~kg} / \mathrm{m}^{2}, 18.5$ $\mathrm{kg} / \mathrm{m}^{2} \leq \mathrm{BMI}<30 \mathrm{~kg} / \mathrm{m}^{2}, \mathrm{BMI} \geq 30 \mathrm{~kg} / \mathrm{m}^{2}$ ), smoking status (no smoking, smoking during pregnancy, smoking before but not during pregnancy), and educational level (primary, high school, university, outof-school).

\subsection{Statistical methods}

For the analyses of residential proximity to agricultural pesticide applications, we excluded women living in "strictly urban" areas, that is, with an urban surface > 99\% around the home, because we believe that they represent a specific population in terms of lifestyle, environmental exposures, and socioeconomic profiles $(n=5,761)$. Quantities applied of the different agricultural pesticides were correlated, which can cause problems in the estimation of regression coefficients (Hoerl and Kennard 1970a). When predictors are not orthogonal in standard regression models, the coefficients tend to become too large in absolute value; large variance can even cause them to have the wrong sign. The ridge regression model (Hoerl and Kennard 1970a, 1970b) allows highly correlated exposure variables to be modeled without encountering collinearity issues by penalizing the size of the regression coefficients (Huang et al. 2017). The optimal $\lambda$ parameter (degree of penalization) was defined by using 10-fold cross-validation to obtain the minimum mean square error of the model (Huang et al. 2017) with the glmnet package for $\mathrm{R}$ (Friedman et al. 2010). We forced the model to include some selected potential confounders previously identified. Cross-validation was repeated 100 times, and optimal $\lambda$ values were averaged to overcome stability problems. We used the ridge $\mathrm{R}$ package (Cule and Iorio 2013) to perform the ridge regression with the optimal $\lambda$ previously determined and selected confounders (Cule and Iorio 2013). The $p$-values were computed by applying the significance test of Cule et al. (2011). We selected pesticides associated with the outcome at a $p$-value $<0.2$ in the ridge regression to analyze them together in a standard multivariable logistic regression to obtain unpenalized regression coefficients for these compounds of interest (Huang et al. 2017).

For the analyses on dietary intake of pesticides, we could not use the same approach because of variance inflation factors (VIF, Table S5) above 5, indicating multicollinearity problems in the standard logistic regression model. We thus grouped dietary intakes into clusters of correlated variables, as in Traoré et al. 2018 , using a multiple correspondence analysis and hierarchical ascending classification (Stafoggia et al. 2017). The FactoMineR package (Lê et al. 2008) was used to determine each cluster of dietary intake of pesticides.

As a high consumption of fruits and vegetables has been associated with a decreased risk of preeclampsia (Brantsaeter et al. 2009; Hamad et al. 2019; Mi et al. 2019), but also with higher exposure to several pesticides (Papadopoulou et al. 2019), we created a variable to characterize dietary patterns to serve as an additional adjustment variable in the models focused on dietary exposure. Dietary patterns 
were defined by Principal Component Analysis and clustering to identify clusters of women with similar food patterns, as in previous studies (Brantsaeter et al. 2009; Mi et al. 2019; Schoenaker et al. 2015). We computed a hierarchical clustering of principal components with a k-means consolidation (FactoMineR R package (Lê et al. 2008)) (Kassambara 2017). We identified five food profiles: 1) "breakfast": higher consumption of cocoa, milk, and breakfast cereals; 2) "mixed": higher consumption of tea, honey, wholegrain bread, butter, yogurt, vegetables, fruits, coffee, cheese, bread, chocolate, cream, eggs, fish, and soy; 3) "healthy": higher consumption of fresh fruit, dried fruit, soy, and vegetables; 4) "fat": higher consumption of sweet snacks, cakes, spreads, sodas, potato chips, and French fries; 5) "big eaters": women included in this profile ate all food items in greater quantities than the others.

Associations between domestic pesticide uses and preeclampsia were analyzed with standard logistic regression that included simultaneously the five selected household pesticide uses.

For adjustment covariables, missing values were replaced by the mode or median value: prepregnancy maternal BMI $\left(18.5 \leq\right.$ BMI $\left.<30 \mathrm{~kg} / \mathrm{m}^{2}, \mathrm{n}=414 ; 2.4 \%\right)$; maternal educational level (university, $\mathrm{n}=190$; $1.1 \%$ ); maternal smoking status (non-smoker; $\mathrm{n}=407 ; 2.3 \%$ ); and maternal age (30.5 years, $\mathrm{n}=195$; $1.1 \%$ ). Exposure and outcome variables were not imputed. Risks were not estimated for exposure variables that had fewer than 5 exposed participants. The three sources of pesticide exposure (household uses, food intake, and agricultural uses near the home) were analyzed separately.

The assumption of linearity of the relation between preeclampsia and maternal age was assessed with the log-likelihood ratio test, by comparing models including maternal age as a categorical variable (four classes: [18-25[, [25-30[, [30-35[, [35-50[) to models with age as a continuous variable. Observing no departure from linearity, we kept maternal age as a continuous variable. Other variables were categorical.

\subsection{Sensitivity analyses}

We performed five sensitivity analyses to test the robustness of our results: 1) stratifying models by weeks of gestation at the preeclampsia diagnosis (before or after 34 gestational weeks); 2) restricting the analyses to women whose first trimester of pregnancy coincided or overlapped with the spring or summer; 3) stratifying models by a proxy for preeclampsia severity (medication to treat hypertension or not); 4) excluding influential outliers (Cook's distance $>0.5$ ); and 5) excluding women with missing data for covariates.

We also grouped agricultural pesticides into clusters of correlated variables by using a multiple correspondence analysis and hierarchical ascending classification to explore the influence of pesticide exposure profiles, as we did with dietary pesticide intakes. 
As we cannot rule out the possibility that preeclampsia in some women was misclassified as gestational hypertension, we included women with gestational hypertension in a second sample and replicated the analysis to assess the association between prenatal pesticide exposures and the risk of gestational hypertension.

All statistics were analyzed with $\mathrm{R}$ version 3.5.3. The level of statistical significance was set at $p<0.05$. 


\section{$\underline{\text { Results }}$}

\section{Population characteristics}

Table 2 describes the study population. The participating women were aged $30.6 \pm 5.0$ years on average, and many (59.6\%) had a university degree. Of the 17,376 participating women, 195 (1.1\%) developed preeclampsia, including $39(20.0 \%)$ who were diagnosed before 34 weeks of gestation and 147 (75.4\%) after that point (9 missing values). Compared with others, women with preeclampsia were more likely to be nulliparous ( $43.0 \%$ vs. $33.1 \%$ ), to have history of gestational hypertension ( $9.7 \%$ vs. $0.9 \%$ ) or of gestational diabetes ( $5.1 \%$ vs. $2.5 \%$ ), to have gestational diabetes during the current pregnancy $(15.9 \%$ vs. $6.4 \%)$, to smoke during the pregnancy $(27.2 \%$ vs. $22.2 \%)$, and to have a BMI $\geq 30 \mathrm{~kg} / \mathrm{m}^{2}(28.7 \%$ vs. $8.9 \%$ ). On average, the newborns of mothers with preeclampsia were born earlier (38 weeks of gestation \pm 2 days vs. 39 weeks \pm 1 day) and had a lower birth weight $(2,893 \mathrm{~g} \pm 681$ vs. $3,329 \mathrm{~g} \pm 481)$ than the infants of the other mothers. These characteristics are consistent with the literature for risk factors and consequences of preeclampsia (Mayrink et al. 2018; Mol et al. 2016).

Of the agricultural pesticides used near the residence, the most prevalent were tebuconazole, pyraclostrobin, and cyproconazole $(83.6 \%, 82.0 \%$, and $81.2 \%$ respectively) (Table S3). Less than 50\% of the population was exposed to fenvalerate, diquat, 2,4-dichlorophenoxyacetic acid (2,4 D), dimethoate, maneb, fenoxycarb or bifenthrin (respectively, 44.3\%, 44.0\%, 43.0\%, 31.3\%, 23.2\%, $15.3 \%$, and $1.8 \%$ exposed).

For exposure via maternal diet, more than $95 \%$ of the study population had a dietary intake of tebuconazole, chlorpyrifos, procymidone, and bifenthrin $(99.9 \%, 99.2 \%, 99.2 \%$, and $95.8 \%$ respectively). Less than $25 \%$ of the total population was exposed to 12 of the pesticides of interest (Table S4).

Women with missing data about household pesticide use or dietary pesticide intake were similar to the others (Table S6), except that their educational level was lower.

\section{Associations between pesticide exposures and preeclampsia}

Overall, we did not observe a significant association between preeclampsia and the different reported household pesticide uses during pregnancy (pesticides against crawling insects, use of herbicides, flea collar, other pesticides against fleas and ticks, and fungicides on outdoor plants) in either the crude or adjusted analyses (Table 3 ).

Looking at the quantities of agricultural pesticide applied near mothers' homes, 2 of the 15 pesticides included in the ridge regression model were selected, with a $p$-value $<0.20$ : cypermethrin and prochloraz (Table S7). In crude logistic regression models, women exposed to higher quantities of prochloraz had higher odds ratios (OR) for preeclampsia $(31.4 \%$ vs. $24.9 \%$ in the fourth quartile: $\mathrm{OR}=$ 
1.63; 95\% CI: 1.07, 2.47). At the same time, women exposed to higher quantities of cypermethrin were at lower risk of preeclampsia (19.5\% vs. $25.1 \%$ in the fourth quartile of exposure: $\mathrm{OR}=0.60 ; 95 \% \mathrm{CI}$ : $0.37,0.98$ ) (Table 4). After adjusting for covariates, results remained similar: adjusted OR $[\mathrm{aOR}]=$ 1.54 ; 95\%CI:1.02, 2.35), and aOR=0.59; 95\%CI: 0.36, 0.96), respectively (Table 4).

Multiple correspondence analysis and hierarchical ascending classifications categorized estimated dietary exposures to pesticides into seven clusters (Figure 2). No statistically significant association was found between exposure to pesticide residues in food and preeclampsia (Table 5).

\section{Sensitivity analyses}

When stratifying for gestational age at diagnosis (before or after 34 weeks of gestation), we observed similar results for household pesticide use (Table 6). The analysis of dietary exposure to pesticides (Table 6) showed that women diagnosed before 34 weeks had a significantly higher probability of being exposed to pesticide cluster 5 (carbofuran, atrazine, cypermethrin, and chlordecone) (Figure 2) than the other women $(\mathrm{aOR}=2.23 ; 95 \% \mathrm{CI}: 1.04,4.81)$. The study of residential proximity to application of agricultural pesticides found that women with preeclampsia diagnosed before 34 weeks of gestation had a significantly higher probability of being in the highest quartile of prochloraz application on crops within 1,000 meters of their homes $(50.0 \%$ vs. $24.9 \%$, aOR $=2.25 ; 95 \% \mathrm{CI}: 1.01,5.06)$ (Table 6$)$.

Restricting the analyses to women for whom the first trimester of pregnancy overlapped with spring or summer (Table S8-S9) produced similar results. When we excluded women with missing data for covariates, the associations expressed as ORs remained similar for domestic pesticide exposure and dietary exposure (Table S10-S11), whereas associations observed between preeclampsia and exposure to prochloraz and cypermethrin were not significant (Table S12).

Multiple correspondence analysis and hierarchical ascending classifications categorized agricultural pesticides into three clusters: the first included azole fungicides (including prochloraz), the second two herbicides, and the third mainly insecticides (including cypermethrin) (Figure S3). Women in the highest group of exposure for pesticides from the first cluster (prochloraz is part of cluster 1: epoxiconazole, propiconazole, prochloraz, cyproconazole, tebuconazole, pyraclostrobin) had higher odds ratios $(\mathrm{OR})$ for preeclampsia (adjusted $\mathrm{OR}[\mathrm{aOR}]=1.55 ; 95 \%$ CI:1.03, 2.34) (Table S13). Conversely, women in the highest group of exposure for pesticides from the third cluster (cypermethrin is part of cluster 3: cypermethrin, fenvalerate, chlorpyrifos, maneb, dimethoate, bifenthrin, fenoxycarb) were at lower risk of preeclampsia (aOR=0.60; 95\% CI: 0.40, 0.90)) (Table S13). Associations observed for clusters 1 and 3 with preeclampsia were similar to those observed, respectively, for prochloraz and cypermethrin alone in the main analysis. 
When we stratified our study population by hypertensive treatment administration, we observed that the women with treated hypertension were significantly more likely to have used herbicides at home during pregnancy than the women without this disease ( $\mathrm{OR}=2.20 ; 95 \% \mathrm{CI}: 1.23,3.93)$ (Table S14). The probability of being in the fourth quartile of exposure for the quantity of prochloraz applied in the vicinity remained higher for the women with, versus without, preeclampsia in both subgroups, but the association remained statistically significant only in the group without treatment (untreated women: $\mathrm{aOR}=1.87$; 95\% CI: 1.08, 3.24; treated women: $\mathrm{aOR}=1.28 ; 95 \%$ CI: 0.70, 2.37) (Table S15). Looking at dietary exposure, we observed significant protective associations between preeclampsia and the first and seventh clusters of dietary pesticide intake, but only in the subgroup of treated women (for the first cluster: untreated $\mathrm{aOR}=1.43 ; 95 \% \mathrm{CI}: 0.91,2.26$; treated $\mathrm{aOR}=0.49 ; 95 \% \mathrm{CI}: 0.27,0.90$; for the seventh cluster: untreated $\mathrm{aOR}=1.00 ; 95 \% \mathrm{CI}: 0.62,1.59$; treated $\mathrm{aOR}=0.60 ; 95 \% \mathrm{CI}: 0.37,0.98$ ) (Table S16).

Lastly, when we examined gestational hypertension rather than preeclampsia as a sensitivity analysis, we observed that women with versus without this milder hypertensive disease of pregnancy had a significantly higher probability of having used pesticides against fleas and ticks at home (flea-collar use vs. not: $\mathrm{aOR}=2.48 ; 95 \% \mathrm{CI}: 1.32,4.66$; use vs. nonuse of other forms of pesticides against fleas and ticks: aOR $=1.50 ; 95 \%$ CI: $1.11,2.04)$ (Table S17). Similarly, we did not observe any significant association between the dietary pesticide exposure clusters and gestational hypertension (Table S18). For exposure due to residential proximity to agricultural applications, the ridge regression strategy did not select any of the 15 pesticides at a $p$-value $<0.20$ (Table S19). 


\section{Discussion}

Our analyses comparing pesticide exposures from diet, domestic use, and drift from agricultural crops among women with and without preeclampsia yielded associations that were mainly not statistically significant. Nevertheless, they indicated that the application of prochloraz to crops within a kilometer of the home during pregnancy may be associated with a higher risk of preeclampsia, especially before 34 weeks of gestation. When we applied a clustering method to agricultural pesticide exposure, these associations remained similar in the cluster including prochloraz. In addition, we observed that the women with treated gestational hypertension were more likely to have reported domestic use of herbicides during pregnancy, compared to women without gestational hypertension.

Varshavsky et al. (2019) reviewed the literature on the influence of chemical exposures on maternal health and identified only 10 studies of pesticides and either preeclampsia or gestational hypertension. The results, which focused mainly on organochlorine and organophosphorus pesticides, were inconsistent. The results of organochlorine pesticide biomarker studies were mixed, with two of five suggesting an association with increased risk and the others reporting null or inverse associations. To our knowledge, the impact of prochloraz on preeclampsia has never been specifically studied.

Prochloraz is an imidazole fungicide used in agriculture, in particular for cereals (such as wheat, barley, oat, and rye) and cultivated mushrooms (ANSES 2018). This active substance is approved in the European Union under Regulation (EC) No 1107/2009 for use in plant protection products and is authorized in France on cereals and fungi (ANSES 2020; EC 2020). It has also been detected in several tropical fruits and vegetables in the national monitoring programs (ANSES 2018). The substance was assessed under the regulatory EU pesticide risk assessment process, and its toxicology studied extensively (EFSA 2011). Animal experiments observed developmental toxicity in the form of reduced mean litter size, increased total litter loss, reduced live birth index, impaired growth, and adverse effects on organ weights (EFSA 2011). The results of some interesting studies may explain how prochloraz could contribute to the induction of preeclampsia, by two separate pathways. First, prochloraz increases the expression of PAI-1 (plasminogen activator inhibitor-type 1), also known as endothelial plasminogen activator inhibitor or SERPINE 1 (Kleinstreuer et al. 2011). PAI-1 down-regulates endogenous fibrinolytic activity and thus impairs placental formation and invasion (DossenbachGlaninger et al. 2008). By this fibrinolytic pathway, the PAI-1 gene may contribute to the pathogenesis of preeclampsia (Morgan et al. 2013). Ye et al. observed a higher plasma level of PAI-1 among women with (versus without) preeclampsia during the second trimester of pregnancy. Interestingly, PAI-1 levels increased in women with early-onset preeclampsia (24-32 gestational weeks) compared with the control group, but not in late-onset preeclampsia (35-42 gestational weeks) (Ye et al. 2017), a finding consistent with the association between prochloraz exposure and early preeclampsia. Second, prochloraz inhibits aromatase activity in placental cells (Laville et al. 2006; Sanderson et al. 2002; Vinggaard et al. 
2000), and both the expression and function of placental aromatase are known to be diminished in pregnancies complicated by preeclampsia (Berkane et al. 2018; Perez-Sepulveda et al. 2015).

Our results on residential proximity to agricultural applications are similar to those of Shaw et al. (2018), who observed a statistically significant inverse association between pyrethroids (chemical family including cypermethrin) and preeclampsia ( $\mathrm{OR}=0.79 ; 95 \% \mathrm{CI}: 0.66,0.94)$. They hypothesized that the unexpected direction of this risk might be explained by a selection bias due to early fetal loss associated with pyrethroid exposures (Shaw et al. 2018). The review by Varshavsky et al. (2019) agreed that a live-birth bias might account for this surprising finding.

Another study has reported an association between first-trimester domestic pesticide use and preeclampsia among farmers' wives ( $\mathrm{OR}=1.32 ; 95 \%$ CI: 1.02, 1.70) (Saldana et al. 2009). It should be noted that they might have indirect pesticide exposure related to their husband's job, that is, paraoccupational exposure (Deziel et al. 2015b). Our results showed more frequent household use of herbicides in women with versus without preeclampsia. None of these associations, however, were statistically significant, except in the sensitivity analyses for herbicide use, stratified by hypertensive treatment (yes/no) for women with preeclampsia. In view of the relatively small number of women with preeclampsia exposed to domestic pesticide, we probably lack the power to show a statistically significant association between preeclampsia and domestic usage of pesticides. These results should be interpreted with caution. Moreover, the same type of domestic pesticide use may nonetheless involve different compounds from woman to woman, which could dilute the association.

Our results about dietary exposure to pesticides suggested it might potentially be protective against preeclampsia, but these findings were not statistically significant. Fruit and vegetable intake is associated with reduced risk of preeclampsia (Brantsaeter et al. 2009; Hamad et al. 2019; Ikem et al. 2019; Mi et al. 2019; Schoenaker et al. 2015), at the same time that foods of plant origin are the greatest contributors to pesticide exposure (Nougadère et al. 2012; Papadopoulou et al. 2019). Despite our effort to control for women's food patterns, some residual confounding might persist, since we were not able to control for fruit and vegetable consumption without neutralizing the exposure (overadjustment). Overall, these protective effects might indicate a risk-benefit balance favoring higher intake of vegetables and fruits to reduce the risk of preeclampsia.

Our study defined preeclampsia as gestational hypertension associated with proteinuria, which is the definition commonly used in French hospitals (Collège National des Gynécologues et Obstétriciens Français 2015). In the international literature, on the other hand, it is also defined by the association of gestational hypertension with other symptoms, including acute kidney injury, liver dysfunction, neurological features, hemolysis, thrombocytopenia, and fetal growth restriction (Brown et al. 2018; Mol et al. 2016; Ramos et al. 2017). In consequence, some women with preeclampsia according to the international definition might have been considered to have simple gestational hypertension in our 
study. However, our sensitivity analysis replacing preeclampsia by gestational hypertension did not observe any association between the latter and pesticide exposure, except for household use of insecticides against flea and ticks (both flea collars and other formulations). This latter association is new, to our knowledge. Warembourg et al. (2019) assessed the association between urinary levels of organophosphate pesticide metabolites and blood pressure in pregnant women, by repeated measurements throughout pregnancy and did not observe any association. Likewise, Smarr et al. found no association between preconceptional serum levels of nine organochlorine pesticides and gestational hypertensive disorders (Smarr et al. 2016). In France, fipronil (a phenylpyrazole insecticide) has been one of the main pesticides used against fleas and ticks (ANSES 2010), but to our knowledge, its influence on gestational hypertension has not been explored in the literature.

This study has some limitations. First, the ELFE population was restricted to women who gave birth after 33 weeks of gestation. The effect of this exclusion of a perhaps substantial fraction of the women with early preeclampsia on these measures of association is unknown. In addition, women participating in birth cohorts tend to be healthier than the general population (Nohr and Liew 2018). As only 51\% of women contacted by ELFE agreed to participate in the cohort, women with preeclampsia might be overrepresented in the $49 \%$ who refused to participate. Overall, these may constitute selection biases that would explain the $1.2 \%$ prevalence of preeclampsia in our study, although in the literature it complicates 3-5\% of pregnancies and 2\% of pregnancies in France (Abalos et al. 2013; Mol et al. 2016; Ramos et al. 2017a; Enquête nationale périnatale Rapport 2016).

Second, we must note some uncertainties in the exposure assessment strategy. We were unable to identify which specific active substances were used in households or to verify that the pesticides of interest are really used in the corresponding categories, and we cannot attribute a level of exposure to women. Residential proximity to agricultural application was evaluated with averaged quantities of pesticide usage at the district level to attenuate the impact of misclassification in the desegregation techniques, and we used pesticide sales data from 2014 to estimate the density of pesticides applied to crops in 2011. We also expect the geocoding is less precise for more rural addresses, although these addresses are likely to be more exposed to agricultural pesticides (Béranger et al. 2014b). Dietary exposure to pesticides was estimated with averaged levels of pesticide contamination in food, combined with self-reported food-frequency questionnaires. These questionnaires focused on the last 3 months of pregnancy, whereas preeclampsia most probably results from abnormal placentation during the first trimester of pregnancy. A study comparing dietary profiles before and after pregnancy and including data from the ELFE study concluded that women increase their consumption of fish, butter, milk, cheese and cereal products during pregnancy (Traoré et al. 2018). Nonetheless, these misclassifications were probably nondifferential; in these situations, associations usually tend toward the null (Vrijheid et al. 2006). In addition, previous studies have reported associations between self-reported usage of household pesticides and their contamination of indoor dust. Béranger et al. 2019 reported associations 
between self-reported usage of pesticides against fleas and ticks and higher fipronil levels in house dust in southeastern France. Gardens were also associated with higher levels of propiconazole and tebuconazole in house dust (Béranger et al. 2019). In the USA, increased levels of 2,4D and chlorpyrifos were observed in house dust when inhabitants self-reported the use, respectively, of herbicides on the lawn and insecticides against crawling insects (Colt et al. 2004; Deziel et al. 2015a). Within the ELFE cohort, Béranger et al. 2018 also observed higher levels of cypermethrin and fipronil in the hair of women who self-reported using pesticides, respectively, for crawling insects and against fleas and ticks. Moreover, positive and statistically significant correlations have been reported between the quantities of active pesticide ingredients applied within a distance of 500 or 1250 meters from households and the contamination of indoor dust collected in these households (Gunier et al. 2011). These results have been confirmed by studies in France, where, based on the ELFE and the PELAGIE French birth cohorts, respectively, Dereumeaux et al. and Glorennec et al. reported increased concentrations of pyrethroid pesticide metabolites in urine of inhabitants living close to orchards and vineyards (Dereumeaux et al. 2018), grains, vegetables, and flower crops (Glorennec et al. 2017), or reporting using pesticides in and around the home. Finally, Chui et al. (2018) estimated dietary pesticide residue intake in one study of 90 men from the EARTH cohort, using a method similar to that of de Gavelle et al. (2016), based on a food frequency questionnaire and data monitoring pesticide residues in food. They successfully correlated their estimated exposure with urinary concentrations of several pesticide biomarkers. All these results tend to support the reliability of the exposure assessment strategies used on our study.

The third limitation is that because we performed multiple statistical tests in our analyses, we cannot rule out the presence of false positives.

Our study also has multiple strengths, including the large sample size for a birth cohort $(n=17,376)$, which enabled us to focus on preeclampsia, which is a fairly rare disease, in a cohort design. In addition, the ELFE cohort was designed to be representative of the French general population of pregnant women; our data included detailed information on a wide range of personal and medical characteristics and thus allowed us to take various potential confounders into account. We were able to focus our analyses on multiple sources of pesticide exposure and on specific pesticides or subgroups of pesticides; such analyses are useful for prevention strategies by public agencies. The use of toxicogenomic data to select the pesticides of interest was original and made it possible to reduce the number of statistical tests with a priori hypotheses and thus compensated for a common limitation in fully exploratory approaches. 


\section{Conclusion}

This study investigated the association between pesticide exposure through different non-occupational sources (e.g., household uses, dietary exposure, residential proximity to agricultural pesticide application) and the risk of preeclampsia during pregnancy. Pesticides and the corresponding exposure sources were selected a priori based on toxicogenomic approaches. No significant statistical association was found between dietary exposure to pesticide residues in food and preeclampsia. Our findings did suggest, however, that higher quantities of prochloraz were applied for agricultural use near the households of women with preeclampsia. We also observed that some domestic exposures (use of herbicides and insecticides against fleas and ticks) might be associated with preeclampsia and gestational hypertension, respectively, in some subgroups. These results were supported by toxicological mechanistic data, but chance findings cannot be excluded, considering the number of statistical tests performed. These findings should be replicated.

\section{Acknowledgments}

The ELFE survey is a joint project of the French Institute for Demographic Studies (INED) and the National Institute of Health and Medical Research (INSERM), in partnership with the French blood transfusion service (Etablissement français du sang, EFS), Santé publique France, the National Institute for Statistics and Economic Studies (INSEE), the Direction générale de la santé (DGS, part of the Ministry of Health and Social Affairs), the Direction générale de la prévention des risques (DGPR, Ministry for the Environment), the Direction de la recherche, des études, de l'évaluation et des statistiques (DREES, Ministry of Health and Social Affairs), the Département des études, de la prospective et des statistiques (DEPS, Ministry of Culture), and the Caisse nationale des allocations familiales (CNAF), with the support of the Ministry of Higher Education and Research and the Institut national de la jeunesse et de l'éducation populaire (INJEP). Via the RECONAI platform, it receives a government grant managed by the National Research Agency under the "Investissements d'avenir" programme (ANR-11-EQPX-0038). We also thank the families for participating in the study, and Jo Ann Cahn for editorial assistance. 


\section{References}

Abalos E, Cuesta C, Grosso AL, Chou D, Say L. 2013. Global and regional estimates of preeclampsia and eclampsia: a systematic review. Eur J Obstet Gynecol Reprod Biol 170:1-7; doi:10.1016/j.ejogrb.2013.05.005.

ANSES. 2014. Avis de l'Agence nationale de sécurité sanitaire de l'alimentation, de l'environnement et du travail relatif à l'actualisation des indicateurs de risque alimentaire lié aux résidus de pesticides. Available: https://www.anses.fr/fr/system/files/AUT2013sa0138.pdf [accessed 15 July 2020].

ANSES. 2020. E-Phy, Le catalogue des produits phytopharmaceutiques et de leurs usages, des matières fertilisantes et des supports de culture autorisés en France. Available: https://ephy.anses.fr/ [accessed 15 July 2020].

ANSES. 2010. Exposition de la population générale aux pesticides: synthèse et recommandations du comité d'orientation et de prospective scientifique de l'observatoire des résidus de pesticides. Available: https://bretagne-environnement.fr/exposition-de-la-population-generale-auxpesticides-synthese-et-recommandations-du-comite-d-orientation-et-de-prospectivescientifique-de-l-observatoire-des-residus-de-pesticides [accessed 27 May 2020].

ANSES. 2018. Prochloraz, Phytopharmacovigilance, Synthèse des données de surveillance. Available: https://www.anses.fr/fr/system/files/Fiche_PPV_Prochloraz.pdf [accessed 15 July 2020].

Béranger R. 2014. Testicular germ cell tumors: assessing the impact of occupational and environmental exposure to pesticides. Santé publique et épidémiologie. Université Claude Bernard - Lyon I.

Available at: https://tel.archives-ouvertes.fr/tel-01132375/document

Béranger R, Billoir E, Nuckols JR, Blain J, Millet M, Bayle M-L, et al. 2019. Agricultural and domestic pesticides in house dust from different agricultural areas in France. Environ Sci Pollut Res Int 26:19632-19645; doi:10.1007/s11356-019-05313-9.

Béranger R, Blain J, Baudinet C, Faure E, Fléchon A, Boyle H, et al. 2014. [Testicular germ cell tumours and early exposures to pesticides: The TESTEPERA pilot study]. Bull Cancer (Paris) 101:225-235; doi:10.1684/bdc.2014.1901.

Béranger R, Hardy EM, Dexet C, Guldner L, Zaros C, Nougadère A, et al. 2018. Multiple pesticide analysis in hair samples of pregnant French women: Results from the ELFE national birth cohort. Environ Int 120:43-53; doi:10.1016/j.envint.2018.07.023.

Berkane N, Liere P, Lefevre G, Alfaidy N, Nahed RA, Vincent J, et al. 2018. Abnormal steroidogenesis and aromatase activity in preeclampsia. Placenta 69:40-49; doi:10.1016/j.placenta.2018.07.004.

Brantsaeter AL, Haugen M, Samuelsen SO, Torjusen H, Trogstad L, Alexander J, et al. 2009. A dietary pattern characterized by high intake of vegetables, fruits, and vegetable oils is associated with reduced risk of preeclampsia in nulliparous pregnant Norwegian women. J Nutr 139:11621168; doi:10.3945/jn.109.104968.

Brown MA, Magee LA, Kenny LC, Karumanchi SA, McCarthy FP, Saito S, et al. 2018. Hypertensive Disorders of Pregnancy: ISSHP Classification, Diagnosis, and Management Recommendations for International Practice. Hypertens Dallas Tex 1979 72:24-43; doi:10.1161/HYPERTENSIONAHA.117.10803. 
Charles MA, Thierry X, Lanoe J-L, Bois C, Dufourg M-N, Popa R, et al. 2019. Cohort Profile: The French National cohort of children ELFE: birth to 5 years. Int $J$ Epidemiol; doi:10.1093/ije/dyz227.

Collège National des Gynécologues et Obstétriciens Français. 2015. HTA et grossesse, consensus d'experts.

Colt JS, Lubin J, Camann D, Davis S, Cerhan J, Severson RK, et al. 2004. Comparison of pesticide levels in carpet dust and self-reported pest treatment practices in four US sites. J Expo Anal Environ Epidemiol 14:74-83; doi:10.1038/sj.jea.7500307.

Couteux A, Lejeune V. 2010. Index phytosanitaire ACTA 2011. 47e édition. Acta:Paris.

Cule E, Iorio MD. 2013. Ridge Regression in Prediction Problems: Automatic Choice of the Ridge Parameter. Genet Epidemiol 37:704-714; doi:10.1002/gepi.21750.

Cule E, Vineis P, De Iorio M. 2011. Significance testing in ridge regression for genetic data. BMC Bioinformatics 12:372; doi:10.1186/1471-2105-12-372.

Dadvand P, Ostro B, Amato F, Figueras F, Minguillón M-C, Martinez D, et al. 2014. Particulate air pollution and preeclampsia: a source-based analysis. Occup Environ Med 71:570-577; doi:10.1136/oemed-2013-101693.

de Gavelle E, de Lauzon-Guillain B, Charles M-A, Chevrier C, Hulin M, Sirot V, et al. 2016. Chronic dietary exposure to pesticide residues and associated risk in the French ELFE cohort of pregnant women. Environ Int 92-93:533-542; doi:10.1016/j.envint.2016.04.007.

Dereumeaux C, Saoudi A, Goria S, Wagner V, De Crouy-Chanel P, Pecheux M, et al. 2018. Urinary levels of pyrethroid pesticides and determinants in pregnant French women from the Elfe cohort. Environ Int 119:89-99; doi:10.1016/j.envint.2018.04.042.

Dereumeaux C, Saoudi A, Pecheux M, Berat B, de Crouy-Chanel P, Zaros C, et al. 2016. Biomarkers of exposure to environmental contaminants in French pregnant women from the Elfe cohort in 2011. Environ Int 97:56-67; doi:10.1016/j.envint.2016.10.013.

Deschamps V, de Lauzon-Guillain B, Lafay L, Borys J-M, Charles MA, Romon M. 2009. Reproducibility and relative validity of a food-frequency questionnaire among French adults and adolescents. Eur J Clin Nutr 63:282-291; doi:10.1038/sj.ejcn.1602914.

Deziel NC, Colt JS, Kent EE, Gunier RB, Reynolds P, Booth B, et al. 2015a. Associations between selfreported pest treatments and pesticide concentrations in carpet dust. Environ Health Glob Access Sci Source 14:27; doi:10.1186/s12940-015-0015-x.

Deziel NC, Friesen MC, Hoppin JA, Hines CJ, Thomas K, Freeman LEB. 2015b. A review of nonoccupational pathways for pesticide exposure in women living in agricultural areas. Environ Health Perspect 123:515-524; doi:10.1289/ehp.1408273.

Dossenbach-Glaninger A, van Trotsenburg M, Schneider B, Oberkanins C, Hopmeier P. 2008. ACE I/D polymorphism and recurrent first trimester pregnancy loss: interaction with SERPINE1 4G/5G and F13 Val34Leu polymorphisms. Br J Haematol 141:269-271; doi:10.1111/j.13652141.2008.07058.x.

EC. 2020. EU Pesticides database - European Commission. Available: https://ec.europa.eu/food/plant/pesticides/eu-pesticidesdatabase/public/?event=activesubstance.selection\&language=EN [accessed 15 July 2020]. 
EFSA. 2020. Chemical hazards data - OpenFoodTox. Eur Food Saf Auth. Available: http://www.efsa.europa.eu/en/data/chemical-hazards-data [accessed 17 July 2020].

EFSA. 2011. Peer Review of the pesticide risk assessment of the active substance prochloraz. Eur Food Saf Auth. Available: https://www.efsa.europa.eu/en/efsajournal/pub/2323 [accessed 15 July 2020].

Enquête nationale périnatale Rapport 2016. EPOPé Inserm. Available: http://www.xn--epop-insermebb.fr/wp-content/uploads/2017/10/ENP2016_rapport_complet.pdf.

European Commission. 2020. EU Pesticides database. Available: https://ec.europa.eu/food/plant/pesticides/eu-pesticidesdatabase/public/?event=activesubstance.selection\&language=EN [accessed 17 July 2020].

Eurostat. 2020. Available: https://ec.europa.eu/eurostat/fr/web/products-datasets//AEI_FM_SALPEST09 [accessed 27 May 2020].

Friedman J, Hastie T, Tibshirani R. 2010. Regularization Paths for Generalized Linear Models via Coordinate Descent. J Stat Softw 33: 1-22.

Glorennec P, Serrano T, Fravallo M, Warembourg C, Monfort C, Cordier S, et al. 2017. Determinants of children's exposure to pyrethroid insecticides in western France. Environ Int 104:76-82; doi:10.1016/j.envint.2017.04.007.

Gunier RB, Ward MH, Airola M, Bell EM, Colt J, Nishioka M, et al. 2011. Determinants of agricultural pesticide concentrations in carpet dust. Environ Health Perspect 119:970-976; doi:10.1289/ehp.1002532.

Haines DA, Saravanabhavan G, Werry K, Khoury C. 2017. An overview of human biomonitoring of environmental chemicals in the Canadian Health Measures Survey: 2007-2019. Int J Hyg Environ Health 220:13-28; doi:10.1016/j.ijheh.2016.08.002.

Hamad R, Collin DF, Baer RJ, Jelliffe-Pawlowski LL. 2019. Association of Revised WIC Food Package With Perinatal and Birth Outcomes: A Quasi-Experimental Study. JAMA Pediatr; doi:10.1001/jamapediatrics.2019.1706.

Hoerl AE, Kennard RW. 1970a. Ridge regression - Applications to nonorthogonal problems. Technometrics 69-82; doi:10.1080/00401706.1970.10488635.

Hoerl AE, Kennard RW. 1970b. Ridge regression - Biased estimation for nonorthogonal problems. Technometrics 661-6676; doi:10.2307/1267351.

Huang Y-F, Pan W-C, Tsai Y-A, Chang C-H, Chen P-J, Shao Y-S, et al. 2017. Concurrent exposures to nonylphenol, bisphenol A, phthalates, and organophosphate pesticides on birth outcomes: A cohort study in Taipei, Taiwan. Sci Total Environ 607-608:1126-1135; doi:10.1016/j.scitotenv.2017.07.092.

Ikem E, Halldorsson TI, Birgisdóttir BE, Rasmussen MA, Olsen SF, Maslova E. 2019. Dietary patterns and the risk of pregnancy-associated hypertension in the Danish National Birth Cohort: a prospective longitudinal study. BJOG Int J Obstet Gynaecol 126:663-673; doi:10.1111/14710528.15593.

Kahn LG, Trasande L. 2018. Environmental Toxicant Exposure and Hypertensive Disorders of Pregnancy: Recent Findings. Curr Hypertens Rep 20:87; doi:10.1007/s1 1906-018-0888-5. 
Kassambara A. 2017. Practical Guide To Principal Component Methods in R: PCA, M(CA), FAMD, $M F A, H C P C$, factoextra. STHDA.

Kleinstreuer NC, Judson RS, Reif DM, Sipes NS, Singh AV, Chandler KJ, et al. 2011. Environmental impact on vascular development predicted by high-throughput screening. Environ Health Perspect 119:1596-1603; doi:10.1289/ehp.1103412.

Laville N, Balaguer P, Brion F, Hinfray N, Casellas C, Porcher J-M, et al. 2006. Modulation of aromatase activity and mRNA by various selected pesticides in the human choriocarcinoma JEG-3 cell line. Toxicology 228:98-108; doi:10.1016/j.tox.2006.08.021.

Le Gall AC, Chavane L, Chatelier JY. 2013. Rapport INERIS - Analyse des données de la BNV-D sur la période 2008 - 2011.

Lê S, Josse J, Husson F. 2008. FactoMineR: An R Package for Multivariate Analysis. J Stat Softw 25:1-18; doi:10.18637/jss.v025.i01.

Lecarpentier E, Tsatsaris V. 2016. Angiogenic balance (sFlt-1/PIGF) and preeclampsia. Ann Endocrinol 77:97-100; doi:10.1016/j.ando.2016.04.007.

Ledda C, Fiore M, Santarelli L, Bracci M, Mascali G, D’Agati MG, et al. 2015. Gestational Hypertension and Organophosphorus Pesticide Exposure: A Cross-Sectional Study. BioMed Res Int 2015:280891; doi:10.1155/2015/280891.

Levario-Carrillo M, Olave ME, Corral DC, Alderete JG, Gagioti SM, Bevilacqua E. 2004. Placental morphology of rats prenatally exposed to methyl parathion. Exp Toxicol Pathol 55:489-496; doi:10.1078/0940-2993-00346.

Mattingly CJ, Colby GT, Forrest JN, Boyer JL. 2003. The Comparative Toxicogenomics Database (CTD). Environ Health Perspect 111:793-795; doi:10.1289/ehp.6028.

Mattingly CJ, Rosenstein MC, Davis AP, Colby GT, Forrest JN, Boyer JL. 2006. The comparative toxicogenomics database: a cross-species resource for building chemical-gene interaction networks. Toxicol Sci Off J Soc Toxicol 92:587-595; doi:10.1093/toxsci/kfl008.

Mayrink J, Costa ML, Cecatti JG. 2018. Preeclampsia in 2018: Revisiting Concepts, Physiopathology, and Prediction. ScientificWorldJournal 2018:6268276; doi:10.1155/2018/6268276.

Mi B, Wen X, Li S, Liu D, Lei F, Liu R, et al. 2019. Vegetable dietary pattern associated with low risk of preeclampsia possibly through reducing proteinuria. Pregnancy Hypertens 16:131-138; doi:10.1016/j.preghy.2019.04.001.

Mol BWJ, Roberts CT, Thangaratinam S, Magee LA, de Groot CJM, Hofmeyr GJ. 2016. Pre-eclampsia. Lancet Lond Engl 387:999-1011; doi:10.1016/S0140-6736(15)00070-7.

Morgan JA, Bombell S, McGuire W. 2013. Association of plasminogen activator inhibitor-type 1 (-675 4G/5G) polymorphism with pre-eclampsia: systematic review. PloS One 8:e56907; doi:10.1371/journal.pone.0056907.

Mostafalou S, Abdollahi M. 2017. Pesticides: an update of human exposure and toxicity. Arch Toxicol 91:549-599; doi:10.1007/s00204-016-1849-x.

Nohr EA, Liew Z. 2018. How to investigate and adjust for selection bias in cohort studies. Acta Obstet Gynecol Scand 97:407-416; doi:10.1111/aogs.13319. 
Nougadère A, Sirot V, Cravedi J-P, Vasseur P, Feidt C, Fussell RJ, et al. 2020. Dietary exposure to pesticide residues and associated health risks in infants and young children - Results of the French infant total diet study. Environ Int 137:105529; doi:10.1016/j.envint.2020.105529.

Nougadère A, Sirot V, Kadar A, Fastier A, Truchot E, Vergnet C, et al. 2012. Total diet study on pesticide residues in France: levels in food as consumed and chronic dietary risk to consumers. Environ Int 45:135-150; doi:10.1016/j.envint.2012.02.001.

Osaka A, Ueyama J, Kondo T, Nomura H, Sugiura Y, Saito I, et al. 2016. Exposure characterization of three major insecticide lines in urine of young children in Japan-neonicotinoids, organophosphates, and pyrethroids. Environ Res 147:89-96; doi:10.1016/j.envres.2016.01.028.

Papadopoulou E, Haug LS, Sakhi AK, Andrusaityte S, Basagaña X, Brantsaeter AL, et al. 2019. Diet as a Source of Exposure to Environmental Contaminants for Pregnant Women and Children from Six European Countries. Environ Health Perspect 127:107005; doi:10.1289/EHP5324.

Pedersen M, Halldorsson TI, Olsen SF, Hjortebjerg D, Ketzel M, Grandström C, et al. 2017. Impact of Road Traffic Pollution on Pre-eclampsia and Pregnancy-induced Hypertensive Disorders. Epidemiol Camb Mass 28:99-106; doi:10.1097/EDE.0000000000000555.

Pedersen M, Stayner L, Slama R, Sørensen M, Figueras F, Nieuwenhuijsen MJ, et al. 2014. Ambient air pollution and pregnancy-induced hypertensive disorders: a systematic review and meta-analysis. Hypertens Dallas Tex 1979 64:494-500; doi:10.1161/HYPERTENSIONAHA.114.03545.

Perez-Sepulveda A, Monteiro LJ, Dobierzewska A, España-Perrot PP, Venegas-Araneda P, GuzmánRojas AM, et al. 2015. Placental Aromatase Is Deficient in Placental Ischemia and Preeclampsia. PloS One 10:e0139682; doi:10.1371/journal.pone.0139682.

Ramos JGL, Sass N, Costa SHM. 2017a. Preeclampsia. Rev Bras Ginecol E Obstet Rev Fed Bras Soc Ginecol E Obstet 39:496-512; doi:10.1055/s-0037-1604471.

Ramos JJ, Huetos O, González S, Esteban M, Calvo E, Pérez-Gómez B, et al. 2017b. Organochlorinated pesticides levels in a representative sample of the Spanish adult population: The Bioambient.es project. Int J Hyg Environ Health 220:217-226; doi:10.1016/j.ijheh.2016.10.005.

Ridano ME, Racca AC, Flores-Martin JB, Fretes R, Bandeira CL, Reyna L, et al. 2017. Impact of chlorpyrifos on human villous trophoblasts and chorionic villi. Toxicol Appl Pharmacol 329:26-39; doi:10.1016/j.taap.2017.05.026.

Saldana TM, Basso O, Baird DD, Hoppin JA, Weinberg CR, Blair A, et al. 2009. Pesticide exposure and hypertensive disorders during pregnancy. Environ Health Perspect 117:1393-1396; doi:10.1289/ehp.0900672.

Sanderson JT, Boerma J, Lansbergen GWA, van den Berg M. 2002. Induction and inhibition of aromatase (CYP19) activity by various classes of pesticides in H295R human adrenocortical carcinoma cells. Toxicol Appl Pharmacol 182:44-54; doi:10.1006/taap.2002.9420.

Schoenaker DAJM, Soedamah-Muthu SS, Callaway LK, Mishra GD. 2015. Prepregnancy dietary patterns and risk of developing hypertensive disorders of pregnancy: results from the Australian Longitudinal Study on Women's Health. Am J Clin Nutr 102:94-101; doi:10.3945/ajen.114.102475.

Shaw GM, Yang W, Roberts EM, Aghaeepour N, Mayo JA, Weber KA, et al. 2018. Residential agricultural pesticide exposures and risks of preeclampsia. Environ Res 164:546-555; doi:10.1016/j.envres.2018.03.020. 
Shrier I, Platt RW. 2008. Reducing bias through directed acyclic graphs. BMC Med Res Methodol 8:70; doi:10.1186/1471-2288-8-70.

Smarr MM, Grantz KL, Zhang C, Sundaram R, Maisog JM, Barr DB, et al. 2016. Persistent organic pollutants and pregnancy complications. Sci Total Environ 551-552:285-291; doi:10.1016/j.scitotenv.2016.02.030.

Stafoggia M, Breitner S, Hampel R, Basagaña X. 2017. Statistical Approaches to Address MultiPollutant Mixtures and Multiple Exposures: the State of the Science. Curr Environ Health Rep 4:481-490; doi:10.1007/s40572-017-0162-z.

Traoré T, Forhan A, Sirot V, Kadawathagedara M, Heude B, Hulin M, et al. 2018. To which mixtures are French pregnant women mainly exposed? A combination of the second French total diet study with the EDEN and ELFE cohort studies. Food Chem Toxicol Int J Publ Br Ind Biol Res Assoc 111:310-328; doi:10.1016/j.fct.2017.11.016.

Vinggaard AM, Hnida C, Breinholt V, Larsen JC. 2000. Screening of selected pesticides for inhibition of CYP19 aromatase activity in vitro. Toxicol Vitro Int J Publ Assoc BIBRA 14:227-234; doi:10.1016/s0887-2333(00)00018-7.

Vrijheid M, Deltour I, Krewski D, Sanchez M, Cardis E. 2006. The effects of recall errors and of selection bias in epidemiologic studies of mobile phone use and cancer risk. J Expo Sci Environ Epidemiol 16:371-384; doi:10.1038/sj.jes.7500509.

Warembourg C, Basagaña X, Seminati C, de Bont J, Granum B, Lyon-Caen S, et al. 2019. Exposure to phthalate metabolites, phenols and organophosphate pesticide metabolites and blood pressure during pregnancy. Int J Hyg Environ Health 222:446-454; doi:10.1016/j.ijheh.2018.12.011.

Weissgerber TL, Mudd LM. 2015. Preeclampsia and Diabetes. Curr Diab Rep 15:579; doi:10.1007/s11892-015-0579-4.

Yang C, Song G, Lim W. 2019. A mechanism for the effect of endocrine disrupting chemicals on placentation. Chemosphere 231:326-336; doi:10.1016/j.chemosphere.2019.05.133.

Ye Y, Vattai A, Zhang X, Zhu J, Thaler CJ, Mahner S, et al. 2017. Role of Plasminogen Activator Inhibitor Type 1 in Pathologies of Female Reproductive Diseases. Int $\mathrm{J}$ Mol Sci 18; doi:10.3390/ijms18081651.

Zhou J, Zhang J, Li F, Liu J. 2016. Triazole fungicide tebuconazole disrupts human placental trophoblast cell functions. J Hazard Mater 308:294-302; doi:10.1016/j.jhazmat.2016.01.055. 


\section{Tables}

Table 1. Pesticides possibly associated with domestic pesticide use in France and potentially associated to preeclampsia

\section{Domestic pesticide uses}

Pesticides used against crawling insects

Herbicides

Flea collar use

Pesticides against fleas and ticks, other than flea collars

Fungicides used on outdoor plants

\section{Corresponding active substances and adjuvants} Chlorpyrifos, cypermethrin, piperonyl butoxide, bifenthrin, decamethrin, indoxacarb, tetramethrin Paraquat, 2,4-dichlorophenoxyacetic acid Diazinon

Fipronil, bioallethrin, piperonyl butoxide, tetramethrin

Tebuconazole, propiconazole 
Table 2. Characteristics of the study population

\begin{tabular}{|c|c|c|c|c|}
\hline & $\begin{array}{c}\text { Missing } \\
\text { data }\end{array}$ & $\begin{array}{l}\text { Study participants } \\
\quad(\mathrm{n}=17,376)\end{array}$ & $\begin{array}{l}\text { Participants } \\
\text { without } \\
\text { preeclampsia } \\
(\mathrm{n}=17,181)\end{array}$ & $\begin{array}{l}\text { Participants with } \\
\text { preeclampsia } \\
\quad(\mathrm{n}=195)\end{array}$ \\
\hline & $\%$ & $\begin{array}{c}\mathrm{n}(\%) \text { or } \\
\text { mean } \pm \mathrm{SE}\end{array}$ & $\begin{array}{l}\mathrm{n}(\%) \text { or } \\
\text { mean } \pm \mathrm{SE}\end{array}$ & $\begin{array}{c}\mathrm{n}(\%) \text { or } \\
\text { mean } \pm \mathrm{SE}\end{array}$ \\
\hline \multicolumn{5}{|l|}{ Maternal characteristics } \\
\hline Age at delivery (years) & 1.1 & $30.6 \pm 5.0$ & $30.6 \pm 5.0$ & $30.4 \pm 5.4$ \\
\hline $\begin{array}{l}\text { Education (highest level) } \\
\text { - Primary }\end{array}$ & 1.1 & $100(0.6)$ & $100(0.6)$ & 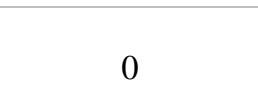 \\
\hline - High school & & $6,687(38.5)$ & $6,606(38.4)$ & $81(41.5)$ \\
\hline - University & & $10,357(59.6)$ & $10,245(59.6)$ & $112(57.4)$ \\
\hline - Out of school & & $45(0.3)$ & $44(0.25)$ & $1(0.5)$ \\
\hline Nulliparous & 1.1 & $5,775(33.2)$ & $5,691(33.1)$ & $84(43.0)$ \\
\hline $\begin{array}{l}\text { Prepregnancy BMI }\left(\mathrm{kg} / \mathrm{m}^{2}\right) \\
\quad-\quad<18.5\end{array}$ & 2.4 & $1,363(7.8)$ & $1,357(7.9)$ & $6(3.1)$ \\
\hline$-\quad 18.5 \leq \mathrm{BMI}<30$ & & $14,020(80.7)$ & $13,890(80.8)$ & $130(66.7)$ \\
\hline$-\quad \geq 30$ & & $1,584(9.1)$ & $1,528(8.9)$ & $56(28.7)$ \\
\hline $\begin{array}{c}\text { Tobacco smoking } \\
-\quad \text { Never }\end{array}$ & 2.3 & $9,726(56.0)$ & $9,608(55.9)$ & $118(60.5)$ \\
\hline - $\quad$ During pregnancy & & $3,871(22.3)$ & $3,818(22.2)$ & $53(27.2)$ \\
\hline $\begin{array}{l}\text { - Before pregnancy but } \\
\text { no during pregnancy }\end{array}$ & & $3,378(19.4)$ & $3,356(19.5)$ & $22(11.3)$ \\
\hline $\begin{array}{l}\text { History of gestational } \\
\text { hypertension (previous } \\
\text { pregnancies) }\end{array}$ & 2.7 & $184(1.1)$ & $165(0.9)$ & $19(9.7)$ \\
\hline $\begin{array}{l}\text { History of gestational diabetes } \\
\text { (previous pregnancies) }\end{array}$ & 3.5 & $445(2.6)$ & $435(2.5)$ & $10(5.1)$ \\
\hline \multicolumn{5}{|l|}{ Child's characteristics } \\
\hline Birth weight $(\mathrm{g})$ & 2.8 & $3,324 \pm 486$ & $3,329 \pm 481$ & $2,893 \pm 681$ \\
\hline Gestational age at birth (weeks) & 2.2 & $39 \pm 2$ & $39 \pm 1$ & $38 \pm 2$ \\
\hline \multicolumn{5}{|l|}{ Pregnancy characteristics } \\
\hline $\begin{array}{l}\text { Treated hypertension during } \\
\text { pregnancy }\end{array}$ & 2.5 & $96(0.6)$ & 0 & $96(49.2)$ \\
\hline Gestational diabetes & 5.6 & $1,135(6.5)$ & $1,104(6.4)$ & $31(15.9)$ \\
\hline - $\quad$ Treated with insulin & & $253(1.5)$ & $242(1.4)$ & $11(5.6)$ \\
\hline - $\quad$ Treated with diet & & $820(4.7)$ & $801(4.7)$ & $19(9.7)$ \\
\hline
\end{tabular}

Abbreviations: BMI, body mass index; SE, standard error. 
Table 3. Risk of preeclampsia associated with domestic pesticide use $(\mathrm{N}=13,573)$

\begin{tabular}{|c|c|c|c|c|c|}
\hline $\begin{array}{l}\text { Domestic } \\
\text { pesticide use }\end{array}$ & $\begin{array}{c}\text { Missing } \\
\text { data } \\
\mathrm{n}(\%)\end{array}$ & $\begin{array}{c}\text { Women without } \\
\text { preeclampsia } \\
(\mathrm{n}=13,423) \\
\text { (exposed/unexposed } \\
\text { women) } \mathrm{n}(\%)\end{array}$ & $\begin{array}{c}\text { Women with } \\
\text { preeclampsia } \\
(\mathrm{n}=150) \\
\text { (exposed/unexposed w } \\
\text { omen) } \\
\mathrm{n}(\%)\end{array}$ & $\begin{array}{l}\text { Crude OR }{ }^{\mathrm{a}} \\
(95 \% \mathrm{CI})\end{array}$ & $\begin{array}{l}\text { Adjusted }^{\mathrm{b}} \text { OR } \\
\quad(95 \% \mathrm{CI})\end{array}$ \\
\hline $\begin{array}{l}\text { Use of } \\
\text { pesticides } \\
\text { against crawling } \\
\text { insects }\end{array}$ & $\begin{array}{l}3,803 \\
(21.8)\end{array}$ & $\begin{array}{c}2,082(15.5) / 11,341 \\
(84.5)\end{array}$ & $\begin{array}{c}29(19.3) / 121 \\
(80.7)\end{array}$ & $\begin{array}{c}1.29 \\
(0.85,1.97)\end{array}$ & $\begin{array}{c}1.27 \\
(0.83,1.94)\end{array}$ \\
\hline Herbicide use & $\begin{array}{l}4,118 \\
(23.7)\end{array}$ & $\begin{array}{c}1,373(10.5) / 11,740 \\
(89.5)\end{array}$ & $\begin{array}{c}19(13.1) / 126 \\
(86.9)\end{array}$ & $\begin{array}{c}1.29 \\
(0.79,2.10)\end{array}$ & $\begin{array}{c}1.25 \\
(0.76,2.05)\end{array}$ \\
\hline Flea-collar use & $\begin{array}{l}4,317 \\
(24.8)\end{array}$ & $328(2.5) / 12,584(97.5)$ & $\begin{array}{c}2(1.4) / 145 \\
(98.6)\end{array}$ & & \\
\hline $\begin{array}{l}\text { Pesticides } \\
\text { against fleas and } \\
\text { ticks (other than } \\
\text { a flea-collar) }\end{array}$ & $\begin{array}{l}4,317 \\
(24.8)\end{array}$ & $3,137(24.3) / 9,775(75.7)$ & $\begin{array}{c}35(23.8) / 112 \\
(76.2)\end{array}$ & $\begin{array}{c}0.97 \\
(0.66,1.44)\end{array}$ & $\begin{array}{c}0.94 \\
(0.63,1.39)\end{array}$ \\
\hline $\begin{array}{l}\text { Use of } \\
\text { fungicides } \\
\text { against outdoor } \\
\text { plants }\end{array}$ & $\begin{array}{l}3,833 \\
(22.1)\end{array}$ & $150(1.1) / 13,243(98.9)$ & $\begin{array}{c}3(2.0) / 147 \\
(98.0)\end{array}$ & & \\
\hline
\end{tabular}


Table 4. Risk of preeclampsia associated with residential proximity to applications of agricultural pesticides (defined by a 1000-m radius around households $(\mathrm{kg} / \mathrm{ha}))(\mathrm{N}=10,770)$

\begin{tabular}{|c|c|c|c|c|}
\hline $\begin{array}{l}\text { Residential } \\
\text { proximity to } \\
\text { application of } \\
\text { agricultural } \\
\text { pesticide }\end{array}$ & $\begin{array}{c}\text { Women without } \\
\text { preeclampsia } \\
(\mathrm{n}=10,652) \\
\text { (fourth quartile/first } 3 \\
\text { quartiles) } \\
\mathrm{n}(\%)\end{array}$ & $\begin{array}{c}\text { Women with } \\
\text { preeclampsia } \\
(\mathrm{n}=118) \\
\text { (fourth quartile/first } 3 \\
\text { quartiles) } \\
\mathrm{n}(\%)\end{array}$ & $\begin{array}{l}\text { Crude OR }{ }^{\mathrm{a}} \\
(95 \% \mathrm{CI})\end{array}$ & $\begin{array}{c}\text { Adjusted } \mathrm{OR}^{\mathrm{b}} \\
95 \% \mathrm{CI})\end{array}$ \\
\hline Cypermethrin & $2,670(25.1) / 7,982(74.9)$ & $23(19.5) / 95(80.5)$ & $\begin{array}{c}0.60 \\
(0.37,0.98)\end{array}$ & $\begin{array}{c}0.59 \\
(0.36,0.96)\end{array}$ \\
\hline Prochloraz & $2,656(24.9) / 7,996(75.1)$ & $37(31.4) / 81(68.6)$ & $\begin{array}{c}1.63 \\
(1.07,2.47)\end{array}$ & $\begin{array}{c}1.54 \\
(1.02,2.35)\end{array}$ \\
\hline
\end{tabular}

Missing data about covariables were imputed as the mode or median value.

${ }_{a}$ The logistic regression was adjusted for the other pesticides shown in the table.

${ }_{b}$ The logistic regression was adjusted for maternal age, BMI, smoking status, and educational level, and for the other domestic pesticide uses shown in the table. 
Table 5. Risk of preeclampsia associated with dietary exposure to pesticides $(\mathrm{N}=13,570)$

\begin{tabular}{|c|c|c|c|c|}
\hline $\begin{array}{l}\text { Clusters } \\
\text { of dietary } \\
\text { pesticide } \\
\text { intake }\end{array}$ & $\begin{array}{c}\text { Women without } \\
\text { preeclampsia } \\
(\mathrm{n}=13,410) \\
\text { (exposed/unexposed women) } \\
\mathrm{n}(\%)\end{array}$ & $\begin{array}{l}\text { Women with preeclampsia } \\
(\mathrm{n}=160) \\
\text { (exposed/unexposed women) } \\
\mathrm{n}(\%)\end{array}$ & $\begin{array}{l}\text { Crude OR }{ }^{\mathrm{a}} \\
(95 \% \mathrm{CI})\end{array}$ & $\begin{array}{c}\text { Adjusted } \\
\text { OR }^{\mathrm{b}}(95 \% \\
\text { CI) }\end{array}$ \\
\hline 1 & $4,022(30.0) / 9,388(70.0)$ & $40(25.0) / 120(75.0)$ & $\begin{array}{c}0.87 \\
(0.60,1.25)\end{array}$ & $\begin{array}{c}0.88 \\
(0.61,1.26)\end{array}$ \\
\hline 2 & 4,951 (36.9)/8,459 (63.1) & $43(26.8) / 117(73.1)$ & $\begin{array}{c}0.77 \\
(0.54,1.12)\end{array}$ & $\begin{array}{c}0.85 \\
(0.58,1.24)\end{array}$ \\
\hline 3 & $3,398(25.3) / 10,012(74.7)$ & $26(16.3) / 134(83.7)$ & $\begin{array}{c}0.72 \\
(0.47,1.12)\end{array}$ & $\begin{array}{c}0.80 \\
(0.51,1.25)\end{array}$ \\
\hline 4 & $3,377(25.2) / 10,033(74.8)$ & $34(21.3) / 126(78.7)$ & $\begin{array}{c}0.88 \\
(0.60,1.30)\end{array}$ & $\begin{array}{c}0.88 \\
(0.60,1.30)\end{array}$ \\
\hline 5 & $8,657(64.6) / 4,753(35.4)$ & $92(57.5) / 68(42.5)$ & $\begin{array}{c}1.11 \\
(0.79,1.56)\end{array}$ & $\begin{array}{c}1.10 \\
(0.78,1.53)\end{array}$ \\
\hline 6 & $4,555(34.0) / 8,855(66.0)$ & $46(28.8) / 114(71.2)$ & $\begin{array}{c}0.98 \\
(0.68,1.40)\end{array}$ & $\begin{array}{c}0.93 \\
(0.65,1.33)\end{array}$ \\
\hline 7 & $9,200(68.6) / 4,210(31.4)$ & $85(53.1) / 75(46.9)$ & $\begin{array}{c}0.71 \\
(0.50,1.00)\end{array}$ & $\begin{array}{c}0.76 \\
(0.54,1.07)\end{array}$ \\
\hline
\end{tabular}

Missing data about covariables were imputed as the mode or median value.

${ }_{a}$ The logistic regression was adjusted for the other clusters of pesticides shown in the table.

${ }_{b}$ The logistic regression was adjusted for food profiles, maternal age, BMI, smoking status, and educational level, and for the other pesticide clusters shown in the table.

Cluster 1: cyproconazole, fenoxycarb, dimetomorph, propiconazole, bioallethrin, fipronil, flusilazole, pentachlorophenol, paraquat, diuron, alachlor

Cluster 2: endosulfan, fenvalerate, bifenthrin

Cluster 3: dieldrin, DDT (Dichlorodiphenyltrichloroethane)

Cluster 4: vinclozolin

Cluster 5: carbofuran, atrazine, cypermethrin, chlordecone

Cluster 6: hexachlorophenol, diazinon

Cluster 7: epiconazole, malathion, chlorpyrifos, dimethoate, procymidone, tebuconazole 
Table 6. Risk of preeclampsia associated with domestic pesticide use, with residential proximity to agricultural pesticide application and with dietary exposure to pesticides by gestational age at preeclampsia diagnosis (before/after 34 gestation weeks) $(\mathrm{N}=13,533)$

\begin{tabular}{|c|c|c|c|c|c|c|c|c|}
\hline & & & \multicolumn{3}{|c|}{ Diagnostic before 34 gestation weeks ( $\mathrm{N}=39$ women) } & \multicolumn{3}{|c|}{ Diagnostic after 34 gestation weeks ( $\mathrm{N}=147$ women) } \\
\hline & & $\begin{array}{c}\text { Women without } \\
\text { preeclampsia } \\
\text { n }(\%)\end{array}$ & $\begin{array}{l}\text { Women with } \\
\text { preeclampsia } \\
\mathrm{n}(\%)\end{array}$ & $\begin{array}{l}\text { Crude } \mathrm{OR}^{\mathrm{a}}(95 \% \\
\mathrm{CI})\end{array}$ & $\begin{array}{l}\text { Adjusted } \mathrm{OR}^{\mathrm{b}} \\
\quad(95 \% \mathrm{CI})\end{array}$ & $\begin{array}{c}\text { Women with } \\
\text { preeclampsia } \\
\mathrm{n}(\%)\end{array}$ & $\begin{array}{c}\text { Crude } \mathrm{OR}^{\mathrm{a}}(95 \% \\
\text { CI })\end{array}$ & $\begin{array}{l}\text { Adjusted } \mathrm{OR}^{\mathrm{b}} \\
\quad(95 \% \mathrm{CI})\end{array}$ \\
\hline \multirow{5}{*}{$\begin{array}{l}\text { Domestic } \\
\text { pesticide } \\
\text { use }^{1}\end{array}$} & $\begin{array}{l}\text { Use of pesticides against } \\
\text { crawling insects }\end{array}$ & $\begin{array}{c}2,082(15.5) / 11,341 \\
(84.5)\end{array}$ & $8(26.7) / 22(73.3)$ & $1.64(0.74,3.60)$ & $1.54(0.69,3.40)$ & $\begin{array}{c}20(17.7) / 93 \\
(82.3)\end{array}$ & $1.16(0.71,1.88)$ & $1.15(0.71,1.87)$ \\
\hline & Herbicide use & $\begin{array}{c}1,373(10.5) / 11,740 \\
(89.5)\end{array}$ & $4(13.8) / 25(86.2)$ & - & 3 & $\begin{array}{c}15(13.8) / 94 \\
\quad(86.2)\end{array}$ & $1.25(0.72,2.17)$ & $1.19(0.69,2.08)$ \\
\hline & Flea-collar use & $\begin{array}{c}328(2.5) / 12,584 \\
(97.5)\end{array}$ & $1(3.6) / 27(96.4)$ & & - & $\begin{array}{c}1(0.9) / 111 \\
(99.1)\end{array}$ & - & - \\
\hline & $\begin{array}{l}\text { Use of pesticides other } \\
\text { than flea collars against } \\
\text { fleas and ticks }\end{array}$ & $\begin{array}{c}3,137(24.3) / 9,775 \\
(75.7)\end{array}$ & $6(21.4) / 22(78.6)$ & $0.64(0.27,1.55)$ & $0.64(0.27,1.56)$ & $\begin{array}{c}29(25.9) / 83 \\
\quad(74.1)\end{array}$ & $1.00(0.65,1.53)$ & $0.96(0.62,1.49)$ \\
\hline & $\begin{array}{l}\text { Fungicide use for outdoor } \\
\text { plants }\end{array}$ & $\begin{array}{c}150(1.1) / 13,243 \\
(98.9)\end{array}$ & $0(0) / 30(100)$ & - & - & $\begin{array}{c}3(2.6) / 113 \\
(97.4)\end{array}$ & - & - \\
\hline \multirow{2}{*}{$\begin{array}{l}\text { Residential } \\
\text { proximity to } \\
\text { agricultural } \\
\text { pesticide } \\
\text { applications }{ }^{2}\end{array}$} & Cypermethrin & $\begin{array}{c}2670(25.1) / 7,982 \\
(74.9)\end{array}$ & 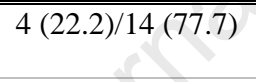 & $0.58(0.22-1.53)$ & $0.57(0.22,1.51)$ & $\begin{array}{c}17(18.9) / 73 \\
(81.1)\end{array}$ & $\begin{array}{c}0.62(0.36- \\
1.06)\end{array}$ & $0.61(0.36,1.04)$ \\
\hline & Prochloraz & $\begin{array}{c}2,656(24.9) / 7,996 \\
(75.1)\end{array}$ & $9(50.0) / 9(50.0)$ & $2.33(1.04,5.25)$ & $2.25(1.01,5.06)$ & $\begin{array}{l}26(28.9) / 64 \\
\quad(71.1)\end{array}$ & $1.37(0.86,2.19)$ & $1.29(0.81,2.07)$ \\
\hline \multirow{7}{*}{$\begin{array}{l}\text { Dietary } \\
\text { exposure to } \\
\text { pesticides }^{3}\end{array}$} & Cluster 1 & $\begin{array}{c}4,022(30.0) / 9,388 \\
(70.0)\end{array}$ & $5(17.2) / 25(82.8)$ & $0.56(0.24,1.28)$ & $0.59(0.26,1.37)$ & $\begin{array}{c}33(26.6) / 90 \\
(73.4)\end{array}$ & $0.98(0.66,1.45)$ & $0.98(0.66,1.46)$ \\
\hline & Cluster 2 & $\begin{array}{c}4,951(36.9) / 8,459 \\
(63.1)\end{array}$ & $11(36.7) / 19(63.3)$ & $0.76(0.36,1.58)$ & $0.95(0.44,2.04)$ & $\begin{array}{l}43(34.9) / 80 \\
\quad(65.1)\end{array}$ & $0.74(0.49,1.12)$ & $0.78(0.51,1.20)$ \\
\hline & Cluster 3 & $\begin{array}{c}3,398(25.3) / 10,012 \\
(74.7)\end{array}$ & $9(30.0) / 21(70.0)$ & $0.75(0.32,1.76)$ & $0.94(0.39,2.25)$ & $\begin{array}{c}28(22.8) / 95 \\
\quad(77.2)\end{array}$ & $0.75(0.46,1.22)$ & $0.79(0.48,1.31)$ \\
\hline & Cluster 4 & $\begin{array}{c}3,377(25.2) / 10,033 \\
(74.8)\end{array}$ & $5(16.7) / 25(83.3)$ & $0.82(0.37,1.82)$ & $0.85(0.38,1.88)$ & $\begin{aligned} 29 & (23.6) / 94 \\
& (76.4)\end{aligned}$ & $0.96(0.63,1.46)$ & $0.95(0.62,1.45)$ \\
\hline & Cluster 5 & $\begin{array}{c}8,657(64.6) / 4,753 \\
(35.4)\end{array}$ & $21(70.0) / 9(30.0)$ & $2.28(1.05,4.91)$ & $2.23(1.04,4.81)$ & $\begin{array}{c}68(55.3) / 55 \\
\quad(44.7)\end{array}$ & $0.90(0.62,1.30)$ & $0.89(0.62,1.29)$ \\
\hline & Cluster 6 & $\begin{array}{c}4,555(34.0) / 8,855 \\
(66.0)\end{array}$ & $6(20.0) / 24(80.0)$ & $0.99(0.48,2.06)$ & $0.96(0.46,2.00)$ & $\begin{array}{c}44(35.8) / 79 \\
(64.2)\end{array}$ & $0.95(0.64,1.42)$ & $0.90(0.61,1.35)$ \\
\hline & Cluster 7 & $\begin{array}{c}9,200(68.6) / 4,210 \\
(31.4)\end{array}$ & $21(70.0) / 9(30.0)$ & $0.76(0.37,1.56)$ & $0.86(0.42,1.78)$ & $\begin{array}{c}83(67.5) / 10 \\
\quad(32.5)\end{array}$ & $0.69(0.48,1.01)$ & $0.73(0.50,1.07)$ \\
\hline
\end{tabular}

Missing values about covariables were imputed as the mode or median value. 
1 Women's domestic exposure to pesticide was categorized as exposed and unexposed.

2 Residential proximity to agricultural pesticide applications was categorized as fourth quartile and first 3 quartiles.

3 Women's dietary exposure to pesticides was categorized as exposed and unexposed.

a The logistic regression was adjusted for the other domestic pesticide uses shown in the table.

${ }_{b}$ The logistic regression was adjusted for maternal age, BMI, smoking status, and educational level and for the other domestic pesticide uses shown in the table.

Cluster 1: cyproconazole, fenoxycarb, dimetomorph, propiconazole, bioallethrin, fipronil, flusilazole, pentachlorophenol, paraquat, diuron, alachlor

Cluster 2: endosulfan, fenvalerate, bifenthrin

Cluster 3: dieldrin, DDT (Dichlorodiphenyltrichloroethane)

Cluster 4: vinclozolin

Cluster 5: carbofuran, atrazine, cypermethrin, chlordecone

Cluster 6: hexachlorophenol, diazinon

Cluster 7: epiconazole, malathion, chlorpyrifos, dimethoate, procymidone, tebuconazole 


\section{Figures}

Figure 1. Flow chart for the population study

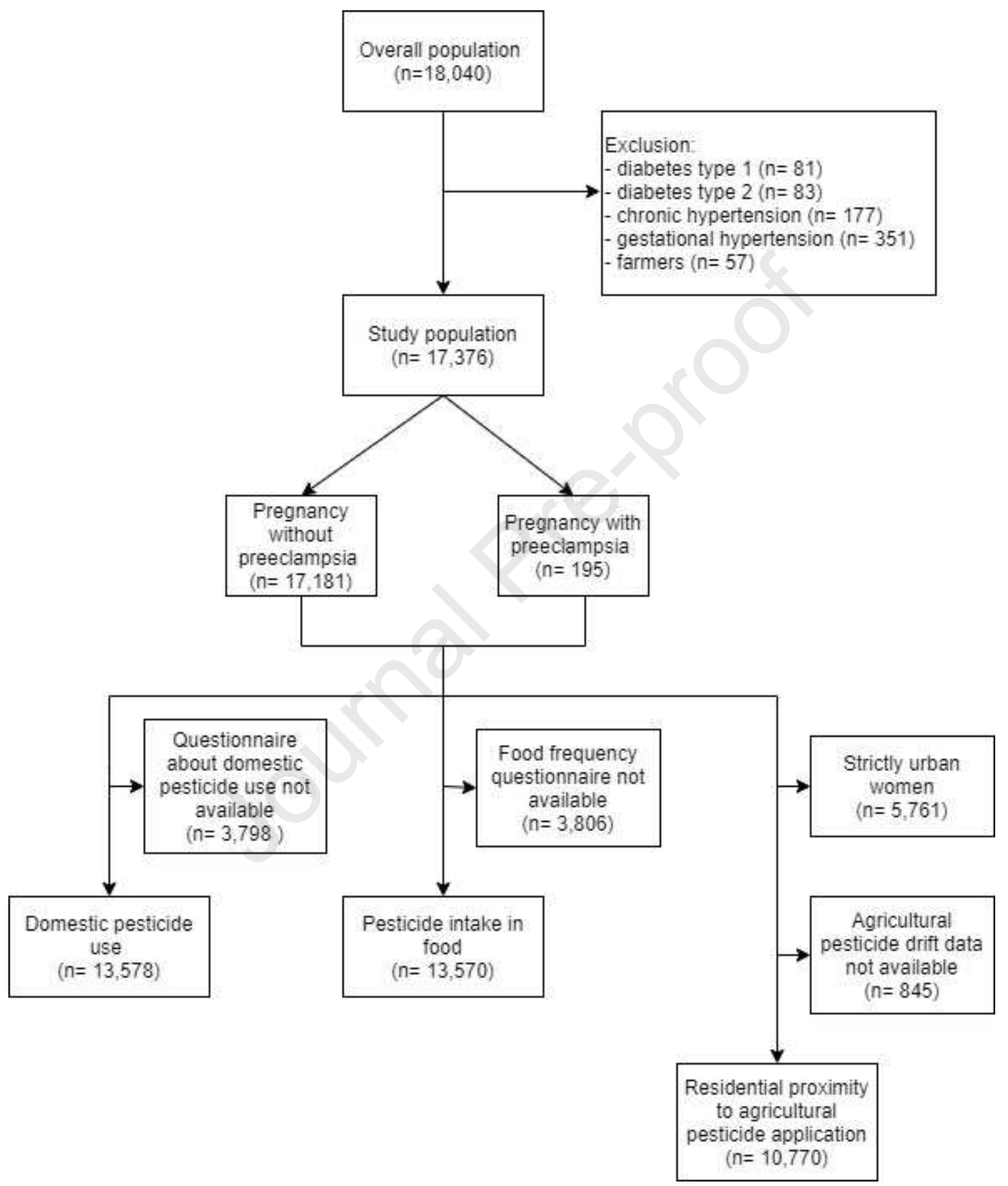


Figure 2. Dietary pesticides allocated into clusters by multiple correspondence analysis and hierarchical ascending classification

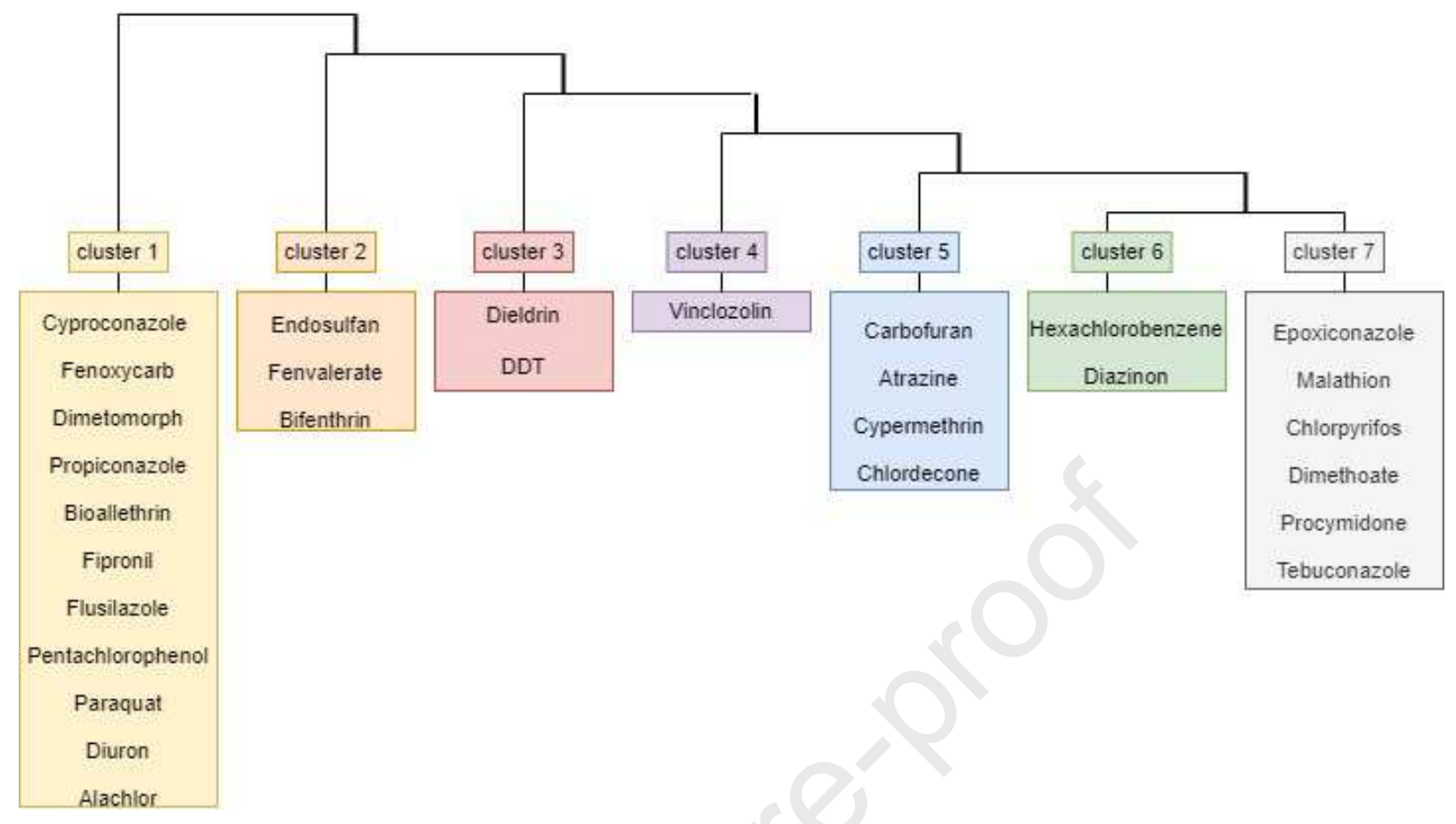

DDT: Dichlorodiphenyltrichloroethane 


\section{Supplemental material}

Table S1. Interactions between pesticides and genes associated with preeclampsia

\begin{tabular}{|c|c|}
\hline $\begin{array}{l}\text { Pesticides Interacting with } \\
\text { Genes }\end{array}$ & Genes Associated with Preeclampsia \\
\hline $\begin{array}{l}\text { 2,4,5-Trichlorophenoxyacetic } \\
\text { Acid }(2,4,5, T)\end{array}$ & EPHX1 (epoxide hydrolase 1) \\
\hline $\begin{array}{l}\text { 2,4-Dichlorophenoxyacetic Acid } \\
\text { (2,4 D) }\end{array}$ & EPHX1 (epoxide hydrolase 1) \\
\hline Alachlor & SERPINE 1 (serpin family E member 1) \\
\hline Atrazine & $\begin{array}{l}\text { ANXA5 (annexin A5) } \\
\text { CORIN (corin, serine peptidase) } \\
\text { CP (ceruloplasmin) } \\
\text { EDN1 (endothelin 1) } \\
\text { EPHX1 (epoxide hydrolase 1) } \\
\text { ERAP1 (endoplasmic reticulum aminopeptidase 1) } \\
\text { NOS } 3 \text { (nitric oxide synthase 3) } \\
\text { ROCK2 (Rho associated coiled-coil containing protein kinase 2) } \\
\text { SERPINE 1 (serpin family E member 1) }\end{array}$ \\
\hline Azametiphos & SERPINE 1 (serpin family E member 1) \\
\hline Bifenthrin & EPHX1 (epoxide hydrolase 1) \\
\hline Bioallethrin & SERPINE 1 (serpin family E member 1 ) \\
\hline Carbofuran & SERPINE 1 (serpin family E member 1 ) \\
\hline Chlordecone & SERPINE 1 (serpin family E member 1 ) \\
\hline Chlorpyrifos & $\begin{array}{l}\text { AGT (angiotensinogen) } \\
\text { ANXA5 (annexin A5) }\end{array}$ \\
\hline Cyazofamif & SERPINE 1 (serpin family E member 1 ) \\
\hline Cypermethrin & $\begin{array}{l}\text { AGT (angiotensinogen) } \\
\text { EPHX1 (epoxide hydrolase 1) }\end{array}$ \\
\hline Cyproconazole & EPHX1 (epoxide hydrolase 1) \\
\hline DDT & EPHX1 (epoxide hydrolase 1) \\
\hline Diazinon & $\begin{array}{l}\text { ARHGAP45 (Rho GTPase activating protein 45) } \\
\text { CP (ceruloplasmin) } \\
\text { EPHX1 (epoxide hydrolase 1) } \\
\text { PIGF (placenta growth factor) }\end{array}$ \\
\hline Dieldrin & $\begin{array}{l}\text { AGT (angiotensinogen) } \\
\text { EPHX1 (epoxide hydrolase 1) } \\
\text { PIGF (placental growth factor) }\end{array}$ \\
\hline Dimethoate & ANXA5 (annexin A5) \\
\hline Dimethomorph & SERPINE 1 (serpin family E member 1) \\
\hline Diniconazole & SERPINE 1 (serpin family E member 1) \\
\hline Diquat & SERPINE 1 (serpin family E member 1) \\
\hline Diuron & $\begin{array}{l}\text { AGT (angiotensinogen) } \\
\text { CP (ceruloplasmin) } \\
\text { DDAH2 (dimethylarginine dimethylaminohydrolase 2) } \\
\text { EPHX1 (epoxide hydrolase 1) }\end{array}$ \\
\hline Endosulfan & $\begin{array}{l}\text { AGT (angiotensinogen) } \\
\text { ARHGAP45 (Rho GTPase activating protein 45) } \\
\text { CORIN (corin, serine peptidase) } \\
\text { CP (ceruloplasmin) } \\
\text { DDAH2 (dimethylarginine dimethylaminohydrolase 2) } \\
\text { EDN1 (endothelin 1) } \\
\text { EPHX1 (epoxide hydrolase 1) }\end{array}$ \\
\hline
\end{tabular}




\begin{tabular}{|c|c|}
\hline & $\begin{array}{l}\text { HMOX1 (heme oxygenase 1) } \\
\text { NOS } 3 \text { (nitric oxide synthase } 3 \text { ) } \\
\text { PLEKHG1 (pleckstrin homology and RhoGEF domain } \\
\text { containing G1) } \\
\text { PIGF (placental growth factor) } \\
\text { ROCK2 (Rho associated coiled-coil containing protein kinase 2) } \\
\text { SERPINE } 1 \text { (serpin family E member 1) }\end{array}$ \\
\hline Epoxiconazole & EPHX1 (epoxide hydrolase 1) \\
\hline Fenoxycarb & SERPINE 1 (serpin family E member 1$)$ \\
\hline Fenvalerate & $\begin{array}{l}\text { ACE (angiotensin I converting enzyme) } \\
\text { EPHX1 (epoxide hydrolase 1) }\end{array}$ \\
\hline Fipronil & EPHX1 (epoxide hydrolase 1) \\
\hline Flusilazole & $\begin{array}{l}\text { AGT (angiotensinogen) } \\
\text { EPHX1 (epoxide hydrolase 1) }\end{array}$ \\
\hline Hexachlorobenzene & $\begin{array}{l}\text { EPHX1 (epoxide hydrolase 1) } \\
\text { NOS } 3 \text { (nitric oxide synthase } 3 \text { ) } \\
\text { SCNN1A (sodium channel epithelial } 1 \text { subunit alpha) }\end{array}$ \\
\hline Indoxacarb & SERPINE 1 (serpin family E member 1$)$ \\
\hline Malathion & EPHX1 (epoxide hydrolase 1) \\
\hline Maneb & SERPINE 1 (serpin family E member 1) \\
\hline Methoxychlor & $\begin{array}{l}\text { ACE (angiotensin I converting enzyme) } \\
\text { CP (ceruloplasmin) } \\
\text { EDN1 (endothelin 1) } \\
\text { SERPINE } 1 \text { (serpin family E member 1) } \\
\text { SCNN1A (sodium channel epithelial } 1 \text { subunit alpha) }\end{array}$ \\
\hline Paraquat & $\begin{array}{l}\text { ACE (angiotensin I converting enzyme) } \\
\text { ACVR2A (activin A receptor type 2A) } \\
\text { AGT (angiotensinogen) } \\
\text { ANXA5 (annexin A5) } \\
\text { DDAH2 (dimethylarginine dimethylaminohydrolase 2) } \\
\text { EDN1 (endothelin 1) } \\
\text { HMOX1 (heme oxygenase 1) } \\
\text { NOS } 3 \text { (nitric oxide synthase 3) } \\
\text { PIGF (placental growth factor) } \\
\text { SCNN1A (sodium channel epithelial } 1 \text { subunit alpha) }\end{array}$ \\
\hline Pentachlorophenol & $\begin{array}{l}\text { EDN1 (endothelin 1) } \\
\text { EPHX1 (epoxide hydrolase 1) } \\
\text { ERAP1 (endoplasmic reticulum aminopeptidase 1) } \\
\text { ROCK2 (Rho associated coiled-coil containing protein kinase 2) } \\
\text { STOX1 (storkhead box 1) }\end{array}$ \\
\hline Prochloraz & SERPINE 1 (serpin family E member 1) \\
\hline Procymidone & NOS 3 (nitric oxide synthase 3 ) \\
\hline Propiconazole & EPHX1 (epoxide hydrolase 1) \\
\hline Pyraclostrobin & $\begin{array}{l}\text { ANXA5 (annexin A5) } \\
\text { EPHX1 (epoxide hydrolase 1) } \\
\text { SERPINE } 1 \text { (serpin family E member 1) }\end{array}$ \\
\hline Rotenone & $\begin{array}{l}\text { AGT (angiotensinogen) } \\
\text { ANXA5 (annexin A5) } \\
\text { ARHGAP45 (Rho GTPase activating protein 45) } \\
\text { CP (ceruloplasmin) } \\
\text { EDN1 (endothelin 1) } \\
\text { EPHX1 (epoxide hydrolase 1) } \\
\text { FLT1 (fms related tyrosine kinase 1) } \\
\text { NOS } 3 \text { (nitric oxide synthase 3) }\end{array}$ \\
\hline
\end{tabular}




\begin{tabular}{|l|l|}
\hline & SERPINE 1 (serpin family E member 1) \\
\hline Tebuconazole & PIGF (placental growth factor) \\
\hline Vinclozolin & ACE (angiotensin I converting enzyme) \\
& ANXA5 (annexin A5) \\
& CP (ceruloplasmin) \\
& EDN1 (endothelin 1) \\
& EPHX1 (epoxide hydrolase 1) \\
& FLT1 (fms related tyrosine kinase 1) \\
& ROCK2 (Rho associated coiled-coil containing protein kinase 2) \\
& SERPINE 1 (serpin family E member 1) \\
& SCNN1A (sodium channel epithelial 1 subunit alpha) \\
\hline
\end{tabular}

According to the Comparative Toxicogenomics Database (CTD, http://ctdbase.org/). Last search was conducted in April 2020. 
Table S2. Active substances previously analyzed for association with preeclampsia

\section{References}

Savitz DA, Klebanoff MA, Wellenius GA, Jensen ET, Longnecker MP. 2014. Persistent organochlorines and hypertensive disorders of pregnancy. Environ Res 132:1-5; doi:10.1016/j.envres.2014.03.020.

Warembourg C, Basagaña X, Seminati C, de Bont J, Granum B, Lyon-Caen S, et al. 2019. Exposure to phthalate metabolites, phenols and organophosphate pesticide metabolites and blood pressure during pregnancy. Int $\mathbf{J}$ Hyg Environ Health 222:446-454; doi:10.1016/j.ijheh.2018.12.011.

Smarr MM, Grantz KL, Zhang C, Sundaram R, Maisog JM, Barr DB, et al. 2016. Persistent organic pollutants and pregnancy complications. Sci Total Environ 551552:285-291; doi:10.1016/j.scitotenv.2016.02.030.

Ledda C, Fiore M, Santarelli L, Bracci M, Mascali G, D’Agati MG, et al. 2015. Gestational Hypertension and Organophosphorus Pesticide Exposure: A CrossSectional Study. BioMed Res Int 2015:280891; doi:10.1155/2015/280891.

\section{Pesticides analysed}

Hexachlorocyclohexane, DDE, DDT, dieldrin, heptachlor epoxide

Phthalates, phenols, organophosphates

Hexachlorobenzene,

hexachlorocyclohexane, DDT

Chlorpyrifos, diazinon, malathion, parathion 
Table S3. Threshold used to categorize the exposure (residential proximity to agricultural pesticide application) ( $\mathrm{N}=10,770$ women)

\begin{tabular}{|c|c|c|c|}
\hline $\begin{array}{l}\text { Active substances } \\
\text { (residential proximity to } \\
\text { agricultural } \\
\text { application) }\end{array}$ & $\begin{array}{c}\text { Women with an exposure } \\
\text { different from } 0 \\
\mathrm{n}(\%)\end{array}$ & Categorization & $\begin{array}{r}\text { Threshold } \\
\text { (in kg/ha) }\end{array}$ \\
\hline tebuconazole & $9,002(83.6)$ & $\begin{array}{c}\text { First } 3 \text { quartiles/fourth } \\
\text { quartile }\end{array}$ & 2.66 \\
\hline pyraclostrobin & $8,837(82.0)$ & $\begin{array}{c}\text { First } 3 \text { quartiles/fourth } \\
\text { quartile }\end{array}$ & 0.69 \\
\hline cyproconazole & $8,747(81.2)$ & $\begin{array}{l}\text { First 3quartiles/fourth } \\
\text { quartile }\end{array}$ & 0.69 \\
\hline cypermethrin & $8,532(79.2)$ & $\begin{array}{c}\text { First } 3 \text { quartiles/fourth } \\
\text { quartile }\end{array}$ & 0.47 \\
\hline epoxiconazole & $8,179(75.9)$ & $\begin{array}{c}\text { First } 3 \text { quartiles/fourth } \\
\text { quartile }\end{array}$ & 1.36 \\
\hline chlorpyrifos & $7,858(73.0)$ & $\begin{array}{c}\text { First } 3 \text { quartiles/fourth } \\
\text { quartile }\end{array}$ & 0.38 \\
\hline prochloraz & $7,729(71.8)$ & $\begin{array}{l}\text { First } 3 \text { quartiles/fourth } \\
\text { quartile }\end{array}$ & 2.61 \\
\hline propiconazole & $7,335(68.1)$ & $\begin{array}{c}\text { First } 3 \text { quartiles/fourth } \\
\text { quartile }\end{array}$ & 0.86 \\
\hline fenvalerate & $4,766(44.3)$ & $\begin{array}{c}\text { First } 3 \text { quartiles/fourth } \\
\text { quartile }\end{array}$ & 0.01 \\
\hline diquat & $4,741(44.0)$ & $\begin{array}{c}\text { First } 3 \text { quartiles/fourth } \\
\text { quartile }\end{array}$ & 0.27 \\
\hline $\begin{array}{l}\text { 2,4-dichlorophenoxyacetic acid } \\
(2,4 \text { D) }\end{array}$ & $4,628(43.0)$ & $\begin{array}{c}\text { First } 3 \text { quartiles/fourth } \\
\text { quartile }\end{array}$ & 0.40 \\
\hline dimethoate & $3,369(31.3)$ & $\begin{array}{l}\text { First } 3 \text { quartiles/fourth } \\
\text { quartile }\end{array}$ & 0.02 \\
\hline maneb & $2,504(23.2)$ & Not exposed/exposed & $2.38 \times 10^{-6}$ \\
\hline fenoxycarb & $1,648(15.3)$ & Not exposed/exposed & $1.46 \times 10^{-6}$ \\
\hline bifenthrin & $193(1.8)$ & Not exposed/exposed & $5.51 \times 10^{-7}$ \\
\hline
\end{tabular}


Table S4. Threshold values (P75) used to categorize dietary exposure to pesticides ( $\mathrm{N}=13,570$ women)

\begin{tabular}{|c|c|c|}
\hline $\begin{array}{l}\text { Active substances } \\
\text { (dietary exposure to pesticides) }\end{array}$ & $\begin{array}{c}\text { Women with an exposure different from } 0 \\
\mathrm{n}(\%)\end{array}$ & $\begin{array}{c}\text { P75 exposure } \\
\text { (in } \mu \mathrm{g} / \mathrm{kg} \text { of body weight/day). }\end{array}$ \\
\hline tebuconazole & $13,565(99.9)$ & $3.2 \times 10^{-3}$ \\
\hline chlorpyrifos & $13,466(99.2)$ & $1.3 \times 10^{-2}$ \\
\hline procymidone & $13,466(99.2)$ & $1.9 \times 10^{-2}$ \\
\hline bifenthrin & $13,004(95.8)$ & $1.8 \times 10^{-2}$ \\
\hline endosulfan & $12,676(93.4)$ & $1.4 \times 10^{-3}$ \\
\hline DDT & $12,497(92.1)$ & $8.9 \times 10^{-5}$ \\
\hline dieldrin & $12,485(92.0)$ & $5.5 \times 10^{-4}$ \\
\hline epoxiconazole & $11,259(83.0)$ & $5.6 \times 10^{-5}$ \\
\hline cypermethrin & $11,062(81.5)$ & $2.2 \times 10^{-3}$ \\
\hline dimethoate & $10,257(75.6)$ & $1.1 \times 10^{-2}$ \\
\hline hexachlorobenzene & $8,674(63.9)$ & $4.6 \times 10^{-5}$ \\
\hline fenvalerate & $7,539(55.6)$ & $9.2 \times 10^{-4}$ \\
\hline malathion & $5,695(42.0)$ & $5.7 \times 10^{-5}$ \\
\hline atrazine & $5,308(39.1)$ & $4.3 \times 10^{-5}$ \\
\hline diazinon & $5,107(37.6)$ & $1.1 \times 10^{-5}$ \\
\hline vinclozolin & $4,036(29.7)$ & $0.5 \times 10^{-3}$ \\
\hline chlordecone & $3,955(29.1)$ & $1.76 \times 10^{-6}$ \\
\hline carbofuran & $2,613(19.3)$ & $4.9 \times 10^{-6}$ \\
\hline flusilazole & $1,838(13.5)$ & $1.8 \times 10^{-9}$ \\
\hline propiconazole & $1,535(11.3)$ & $7.77 \times 10^{-12}$ \\
\hline cyproconazole & $1,264(9.3)$ & $1.2 \times 10^{-10}$ \\
\hline dimethomorph & $1,116(8.2)$ & $5.3 \times 10^{-11}$ \\
\hline fenoxycarb & $1,084(8.0)$ & $6.7 \times 10^{-12}$ \\
\hline bioallethrin & $722(5.3)$ & $1.2 \times 10^{-10}$ \\
\hline fipronil & $719(5.3)$ & $1.9 \times 10^{-10}$ \\
\hline pentachlorophenol & $300(2.2)$ & $3.0 \times 10^{-12}$ \\
\hline paraquat & $271(1.9)$ & $8.3 \times 10^{-10}$ \\
\hline diuron & $257(1.9)$ & $1.8 \times 10^{-9}$ \\
\hline alachlor & $48(0.3)$ & $3.5 \times 10^{-9}$ \\
\hline
\end{tabular}


Table S5. Variance inflation factors of logistic regression parameters (risk of preeclampsia explained by dietary exposure to pesticides)

\begin{tabular}{|l|c|}
\hline Dietary exposure to pesticides & VIF \\
\hline dieldrin & $1.18 \times 10^{8}$ \\
\hline endosulfan & 1.06 \\
\hline tebuconazole & 1.21 \\
\hline atrazine & 1.02 \\
\hline chlorpyrifos & 1.36 \\
\hline dimethoate & 1.45 \\
\hline epoxyconazole & 1.05 \\
\hline propiconazole & 1.32 \\
\hline DDT & $1.18 \times 10^{8}$ \\
\hline fipronil & $3.70 \times 10^{6}$ \\
\hline hexachlorobenzene & 1.05 \\
\hline bioallethrin & $3.70 \times 10^{6}$ \\
\hline
\end{tabular}

Pesticides were selected with a ridge regression. Ridge regression was adjusted for maternal age, BMI, smoking status, and educational level. The penalized parameter $\lambda$ was determined by using 10 -fold cross-validation $(\lambda=$ $0.02019284)$

VIF $>5$ suggests collinearity issues 
Table S6. Influence of missing values on population selection

\begin{tabular}{|c|c|c|c|c|}
\hline $\begin{array}{l}\text { Parameters } \\
\mathrm{n}(\%) \text { or mean } \pm \text { standard error }\end{array}$ & $\begin{array}{l}\text { Data about } \\
\text { domestic pesticide } \\
\text { use available } \\
(\mathrm{n}=12,750)\end{array}$ & $\begin{array}{c}\text { Missing data about } \\
\text { domestic pesticide } \\
\text { use } \\
(n=4,626)\end{array}$ & $\begin{array}{c}\text { Data about dietary } \\
\text { exposure to pesticides } \\
\text { available } \\
(\mathrm{n}=14,093)\end{array}$ & $\begin{array}{l}\text { Missing data about } \\
\text { dietary exposure to } \\
\text { pesticides } \\
(n=3,949)\end{array}$ \\
\hline Maternal characteristics & $\begin{array}{l}\mathrm{n}(\%) \text { or mean } \pm \\
\mathrm{SE}\end{array}$ & $\begin{array}{l}\mathrm{n}(\%) \text { or mean } \pm \\
\mathrm{SE}\end{array}$ & $\mathrm{n}(\%)$ or mean $\pm \mathrm{SE}$ & $\begin{array}{l}\mathrm{n}(\%) \text { or mean } \pm \\
\mathrm{SE}\end{array}$ \\
\hline Maternal age at birth (years) & $30.8 \pm 4.9$ & $30.0 \pm 5.5$ & $30.8 \pm 4.9$ & $30.2 \pm 5.5$ \\
\hline $\begin{aligned} \text { Education } & \\
- & \text { Primary } \\
- & \text { High school } \\
- & \text { University } \\
- & \text { Out of school }\end{aligned}$ & $\begin{array}{c}39(0.3) \\
4,309(33.8) \\
8,326(65.3) \\
21(0.2)\end{array}$ & $\begin{array}{c}61(1.3) \\
2,378(51.4) \\
2,031(43.9) \\
24(0.5)\end{array}$ & $\begin{array}{c}30(0.2) \\
5,042(35.8) \\
9,003(63.9) \\
18(0.1)\end{array}$ & $\begin{array}{c}74(1.9) \\
1,922(48.7) \\
1,736(44.0) \\
29(0.7)\end{array}$ \\
\hline Nulliparous & $4,417(34.6)$ & $1,358(29.3)$ & $4,715(33.4)$ & $(1,291(32.7)$ \\
\hline $\begin{array}{cl}\text { Prepregnancy BMI }(\mathrm{kg} / \mathrm{m} 2) \\
-\quad<18.5 \\
-\quad 18.5 \leq \mathrm{BMI}<30 \\
-\quad \geq 30\end{array}$ & $\begin{array}{c}951(7.5) \\
10,526(82.6) \\
1,084(8.5)\end{array}$ & $\begin{array}{c}412(8.9) \\
3,494(75.5) \\
500(10.8)\end{array}$ & $\begin{array}{c}1,044(7.4) \\
11,629(82.5) \\
1,384(9.8)\end{array}$ & $\begin{array}{c}341(8.6) \\
2,841(71.9) \\
381(9.6)\end{array}$ \\
\hline $\begin{aligned} \text { Tobacco } & \text { smoking } \\
- & \text { Never } \\
- & \text { During pregnancy } \\
- & \text { Before pregnancy but } \\
& \text { not during pregnancy }\end{aligned}$ & $\begin{array}{l}7,088(55.6) \\
3,06724.1) \\
\\
2,394(18.8)\end{array}$ & $\begin{array}{l}2,638(57.0) \\
804(17.4) \\
\\
984(21.3)\end{array}$ & $\begin{array}{l}7,878(55.9) \\
3,377(24.0) \\
\\
2,717(19.3)\end{array}$ & $\begin{array}{l}2,226(56.4) \\
642(16.3) \\
788(20.0)\end{array}$ \\
\hline $\begin{array}{l}\text { History of gestational } \\
\text { hypertension (previous } \\
\text { pregnancies) }\end{array}$ & $142(1.1)$ & $42(0.9)$ & $186(1.3)$ & $43(1.1)$ \\
\hline $\begin{array}{l}\text { History of gestational diabetes } \\
\text { (previous pregnancies) }\end{array}$ & $306(2.4)$ & $139(3.0)$ & $360(2.6)$ & $109(2.8)$ \\
\hline Child's characteristics & Mean \pm SE & Mean \pm SE & Mean \pm SE & Mean \pm SE \\
\hline Birth weight $(\mathrm{g})$ & $3,334 \pm 476$ & $3,298 \pm 512$ & $3,328 \pm 486$ & $3,298 \pm 502$ \\
\hline $\begin{array}{l}\text { Term at birth (weeks of } \\
\text { gestation) }\end{array}$ & $39 \pm 1.4$ & $39 \pm 1.5$ & $39 \pm 1.4$ & $39 \pm 1.5$ \\
\hline Pregnancy characteristics & $\mathrm{n}(\%)$ & $\mathrm{n}(\%)$ & $\mathrm{n}(\%)$ & $\mathrm{n}(\%)$ \\
\hline $\begin{array}{l}\text { Treated hypertension during } \\
\text { pregnancy }\end{array}$ & $66(0.5)$ & $30(0.6)$ & $194(1.36)$ & $64(1.62)$ \\
\hline $\begin{array}{l}\text { Gestational diabetes } \\
\text { pregnancy }\end{array}$ & $786(6.2)$ & $349(7.5)$ & $968(6.9)$ & $313(7.9)$ \\
\hline
\end{tabular}

Abbreviations: BMI, body mass index; SE, standard error. 
Table S7. Ridge regression results for association between preeclampsia and residential proximity to agricultural application of pesticides $(n=10,770)$

\begin{tabular}{|l|l|l|}
\hline $\begin{array}{l}\text { Estimated amount of agricultural pesticide } \\
\text { applied within 1000m, 4h } \\
\text { others }\end{array}$ & $\beta$ & $p$-value \\
\hline Tebuconazole & $1.05 \times 10^{-3}$ & 0.33 \\
\hline Fenvalerate & $1.05 \times 10^{-3}$ & 0.34 \\
\hline Cypermethrin & $-1.54 \times 10^{-3}$ & 0.16 \\
\hline Chlorpyrifos & $-3.59 \times 10^{-4}$ & 0.74 \\
\hline Dimethoate & $-1.20 \times 10^{-4}$ & 0.91 \\
\hline Pyraclostrobin & $1.06 \times 10^{-4}$ & 0.92 \\
\hline Cyproconazole & $5.76 \times 10^{-4}$ & 0.60 \\
\hline Epoxyconazole & $5.77 \times 10^{-4}$ & 0.60 \\
\hline Propiconazole & $1.03 \times 10^{-4}$ & 0.93 \\
\hline 2,4-dichlorophenoxyacetic acid (2,4 D) & $-8.28 \times 10^{-4}$ & 0.45 \\
\hline Bifenthrin & $2.23 \times 10^{-3}$ & 0.54 \\
\hline Diquat & $-8.28 \times 10^{-4}$ & 0.45 \\
\hline Fenoxycarb & $3.26 \times 10^{-4}$ & 0.81 \\
\hline Maneb & $-1.15 \times 10^{-4}$ & 0.92 \\
\hline Prochloraz & $1.76 \times 10^{-3}$ & 0.11 \\
\hline Abbrevatons: & & \\
\hline
\end{tabular}

Abbreviations: $W G$, weeks of gestation

The ridge regression was adjusted for maternal age, BMI, smoking status, and educational level. The penalized parameter $\lambda$ was determined by using 10 -fold cross-validation $(\lambda=1.043434)$. The quantities of agricultural pesticide applications were expressed as a binary variable (the fourth quartile vs. the first three). 
Table S8. Number of women included by season of first trimester of pregnancy

\begin{tabular}{|l|c|c|}
\hline Inclusion period & Season of first trimester of pregnancy & N $(\%)$ \\
\hline April 1-4, 2011 & spring or summer & $2,638(15.2)$ \\
\hline June 27-July 4, 2011 & autumn or winter & $4,380(25.3)$ \\
\hline September 27-October 4, 2011 & autumn or winter & $4,927(28.5)$ \\
\hline November 28-December 5, 2011 & spring or summer & $5,374(31.0)$ \\
\hline
\end{tabular}


Table S9. Risk of preeclampsia associated with domestic pesticide use $(\mathrm{N}=8,012)$ and with residential proximity to agricultural pesticide applications $(\mathrm{N}=5,020)$, analysis restricted to women whose first trimester of pregnancy was in spring or summer

\begin{tabular}{|c|c|c|c|c|c|}
\hline & & $\begin{array}{c}\text { Women without } \\
\text { preeclampsia } \\
\text { n }(\%)\end{array}$ & $\begin{array}{c}\text { Women with } \\
\text { preeclampsia } \\
\mathrm{n}(\%)\end{array}$ & $\begin{array}{l}\text { Crude OR }{ }^{\mathrm{a}} \\
(95 \% \mathrm{CI})\end{array}$ & $\begin{array}{l}\text { Adjusted } \\
\text { OR }^{\mathrm{b}}(95 \% \\
\quad \mathrm{CI})\end{array}$ \\
\hline \multirow[t]{5}{*}{$\begin{array}{l}\text { Domestic } \\
\text { pesticide use }^{1}\end{array}$} & $\begin{array}{l}\text { Use of pesticides } \\
\text { against } \\
\text { insects }\end{array}$ & $953(15.1) / 5,345(84.9)$ & $13(17.3) / 62(82.7)$ & $\begin{array}{c}1.26 \\
(0.70,2.34)\end{array}$ & $\begin{array}{c}1.26 \\
(0.68,2.31)\end{array}$ \\
\hline & Herbicide use & $586(9.5) / 5,575(90.5)$ & $8(11.1) / 64(88.9)$ & $\begin{array}{c}1.13 \\
(0.54,2.39)\end{array}$ & $\begin{array}{c}1.11 \\
(0.52,2.34)\end{array}$ \\
\hline & Flea collar use & $158(2.6) / 5,850(97.7)$ & $2(2.7) / 72(97.3)$ & - & - \\
\hline & $\begin{array}{l}\text { Use of pesticides } \\
\text { other than flea collars } \\
\text { against fleas and ticks }\end{array}$ & $1,391(23.2) / 4,617(76.8)$ & $20(27.0) / 54(73.0)$ & $\begin{array}{c}1.22 \\
(0.72,2.08)\end{array}$ & $\begin{array}{c}1.21 \\
(0.70,2.06)\end{array}$ \\
\hline & $\begin{array}{l}\text { Use of fungicides for } \\
\text { outdoor plants }\end{array}$ & $61(1.0) / 6,228(99.0)$ & $1(1.3) / 74(98.7)$ & - & - \\
\hline \multirow{2}{*}{$\begin{array}{l}\text { Residential } \\
\text { proximity to } \\
\text { agricultural } \\
\text { pesticide } \\
\text { applications }\end{array}$} & Cypermethrin & $1,224(24.6) / 3,734(75.4)$ & $13(21.0) / 49(79.0)$ & $\begin{array}{c}0.71 \\
(0.37,1.37)\end{array}$ & $\begin{array}{c}0.71 \\
(0.37,1.37)\end{array}$ \\
\hline & Prochloraz & $1,220(24.6) / 3,738(75.4)$ & $18(29.0) / 44$ (71.0) & $\begin{array}{c}1.41 \\
(0.78,2.54)\end{array}$ & $\begin{array}{c}1.35 \\
(0.71,2.43)\end{array}$ \\
\hline
\end{tabular}

Missing data about covariables were imputed as the mode or median value.

1 Women's domestic exposure to pesticide was categorized as exposed and unexposed.

2 Residential proximity to agricultural pesticide applications was categorized as fourth quartile and first 3 quartiles.

${ }_{a}$ The logistic regression was adjusted for the other domestic pesticide uses shown in the table.

${ }_{b}$ The logistic regression was adjusted for maternal age, BMI, smoking status, and educational level and for other domestic pesticide uses shown in the table. 
Table S10. Risk of preeclampsia associated with domestic pesticide use $(\mathrm{N}=13,227)$

\begin{tabular}{|c|c|c|c|c|c|}
\hline $\begin{array}{c}\text { Domestic pesticide } \\
\text { use } \\
\mathrm{n}(\%)\end{array}$ & $\begin{array}{l}\text { Missing } \\
\text { data } \\
\mathrm{n}(\%)\end{array}$ & $\begin{array}{c}\text { Women without } \\
\text { preeclampsia } \\
(\mathrm{n}=13,081) \\
\text { (exposed/unexposed women) } \\
\mathrm{n}(\%)\end{array}$ & $\begin{array}{l}\text { Women with preeclampsia } \\
(\mathrm{n}=146) \\
\text { (exposed/unexposed women) } \\
\mathrm{n}(\%)\end{array}$ & $\begin{array}{l}\text { Crude OR }{ }^{\mathrm{a}} \\
(95 \% \mathrm{CI})\end{array}$ & $\begin{array}{l}\text { Adjusted } \\
\text { OR }^{\mathrm{b}} \\
(95 \% \mathrm{CI})\end{array}$ \\
\hline $\begin{array}{lr}\text { Use of } & \text { pesticides } \\
\text { against } & \text { crawling } \\
\text { insects } & \end{array}$ & $\begin{array}{l}3,545 \\
(21.1)\end{array}$ & $2,027(15.5) / 11,054(84.5)$ & $27(18.5) / 119(81.5)$ & $\begin{array}{c}1.22 \\
(0.79,1.88)\end{array}$ & $\begin{array}{r}1.20 \\
(0.77 \\
1.86)\end{array}$ \\
\hline Herbicide use & $\begin{array}{l}3,856 \\
(23.0)\end{array}$ & $1,353(10.6) / 11,422(89.4)$ & $19(13.5) / 122(86.5)$ & $\begin{array}{c}1.32 \\
(0.81,2.16)\end{array}$ & $\begin{array}{l}1.28 \\
(0.78 \\
2.11)\end{array}$ \\
\hline Flea collar use & $\begin{array}{l}4,039 \\
(24.1)\end{array}$ & $321(2.5) / 12,269(97.5)$ & $2(1.4) / 141(98.6)$ & & \\
\hline $\begin{array}{l}\text { Use of pesticides } \\
\text { (other than flea } \\
\text { collars) against fleas } \\
\text { and ticks }\end{array}$ & $\begin{array}{l}4,039 \\
(24.1)\end{array}$ & $3,070(24.4) / 9,520(75.6)$ & $34(23.8) / 109(76.2)$ & $\begin{array}{c}0.96 \\
(0.65,1.43)\end{array}$ & $\begin{array}{c}0.93 \\
(0.62 \\
1.38)\end{array}$ \\
\hline $\begin{array}{l}\text { Fungicide use for } \\
\text { outdoor plants }\end{array}$ & $\begin{array}{l}3,576 \\
(21.3)\end{array}$ & $146(1.1) / 12,904(98.9)$ & $3(2.1) / 143(97.9)$ & & \\
\hline
\end{tabular}

Women with missing values about covariables were excluded.

${ }_{a}$ The logistic regression was adjusted for the other domestic pesticide uses shown in the table.

${ }_{b}$ The logistic regression was adjusted for maternal age, BMI, smoking status, and educational level and for the other domestic pesticide uses shown in the table. 
Table S11. Risk of preeclampsia associated with dietary pesticide exposure $(\mathrm{N}=13,256)$

\begin{tabular}{|c|c|c|c|c|}
\hline $\begin{array}{c}\text { Dietary } \\
\text { pesticide } \\
\text { clusters } \\
\mathrm{n}(\%)\end{array}$ & $\begin{array}{c}\text { Women without } \\
\text { preeclampsia } \\
(\mathrm{n}=13,100)\end{array}$ & $\begin{array}{c}\text { Women with preeclampsia } \\
(\mathrm{n}=156)\end{array}$ & $\begin{array}{c}\text { Crude OR }^{\mathrm{a}} \\
(95 \% \mathrm{CI})\end{array}$ & $\begin{array}{c}\text { Adjusted OR }^{\mathrm{b}} \\
(95 \% \mathrm{CI})\end{array}$ \\
\hline 1 & $\begin{array}{c}\text { (exposed/unexposed women }) \\
\mathrm{n}(\%)\end{array}$ & & \\
\hline 2 & $3,988(30.4) / 9,112(69.6)$ & $39(25.0) / 117(75.0)$ & $0.84(0.58,1.22)$ & $0.85(0.59,1.24)$ \\
\hline 3 & $4,903(37.4) / 8,197(62.6)$ & $42(27.0) / 114(73.0)$ & $0.76(0.53,1.10)$ & $0.83(0.57,1.22)$ \\
\hline 4 & $3,363(25.7) / 9,737(74.3)$ & $25(16.0) / 131(84.0)$ & $0.70(0.45,1.09)$ & $0.77(0.49,1.22)$ \\
\hline 5 & $3,345(25.5) / 9,755(74.5)$ & $33(21.1) / 123(78.8)$ & $0.86(0.58,1.27)$ & $0.86(0.58,1.27)$ \\
\hline 6 & $8,560(65.3) / 4,540(34.7)$ & $91(58.3) / 65(41.7)$ & $1.12(0.80,1.58)$ & $1.12(0.79,1.55)$ \\
\hline 7 & $4,503(34.4) / 8,597(65.6)$ & $46(29.5) / 110(70.5)$ & $0.99(0.69,1.43)$ & $0.95(0.66,1.36)$ \\
\hline & $9,100(69.5) / 4,000(30.5)$ & $84(53.8) / 72(46.2)$ & $0.71(0.50,1.00)$ & $0.76(0.53,1.07)$ \\
\hline
\end{tabular}

Women with missing values for covariables were excluded.

${ }_{a}$ The logistic regression was adjusted for the other pesticide clusters shown in the table.

${ }_{b}$ The logistic regression was adjusted for the food profiles, maternal age, BMI, smoking status, and educational level and for the other pesticide clusters shown in the table.

Cluster 1: cyproconazole, fenoxycarb, dimetomorph, propiconazole, bioallethrin, fipronil, flusilazole, pentachlorophenol, paraquat, diuron, alachlor

Cluster 2: endosulfan, fenvalerate, bifenthrin

Cluster 3: dieldrin, DDT (Dichlorodiphenyltrichloroethane)

Cluster 4: vinclozolin

Cluster 5: carbofuran, atrazine, cypermethrin, chlordecone

Cluster 6: hexachlorophenol, diazinon

Cluster 7: epiconazole, malathion, chlorpyrifos, dimethoate, procymidone, tebuconazole 
Table S12. Risk of preeclampsia associated with residential proximity to agricultural pesticide application (within a 1000-m radius around the home, in $\mathrm{kg} / \mathrm{ha})(\mathrm{N}=10,514)$

\begin{tabular}{|c|c|c|c|c|}
\hline $\begin{array}{l}\text { Residential } \\
\text { proximity to } \\
\text { agricultural } \\
\text { pesticide } \\
\text { application }\end{array}$ & $\begin{array}{l}\text { Women without preeclampsia } \\
(\mathrm{n}=10,398) \\
\text { (fourth quartile/first } 3 \text { quartiles) } \\
\mathrm{n}(\%)\end{array}$ & $\begin{array}{l}\text { Women with preeclampsia } \\
(\mathrm{n}=116) \\
\text { (fourth quartile/first } 3 \\
\text { quartiles) } \\
\mathrm{n}(\%)\end{array}$ & $\begin{array}{c}\text { Crude OR }{ }^{\mathrm{a}} \\
(95 \% \mathrm{CI})\end{array}$ & $\begin{array}{l}\text { Adjusted OR }{ }^{b} \\
\quad(95 \% \mathrm{CI})\end{array}$ \\
\hline Cypermethrin & $3,654(35.1) / 6,744$ (64.9) & $44(37.9) / 72(62.1)$ & $0.87(0.57,1.33)$ & $0.81(0.53,1.25)$ \\
\hline Prochloraz & $3,676(35.4) / 6,722(64.6)$ & $39(33.6) / 77(66.4)$ & $1.13(0.75,1.72)$ & $1.12(0.74,1.71)$ \\
\hline
\end{tabular}

Women with missing values for covariables were excluded.

${ }_{a}$ The logistic regression was adjusted for the other pesticides shown in the table.

${ }_{b}$ The logistic regression was adjusted for maternal age, BMI, smoking status, and educational level and for the other pesticides shown in the table. 
Table S13. Risk of preeclampsia associated with residential proximity to applications of agricultural pesticides (defined by a 1000-m radius around households $(\mathrm{kg} / \mathrm{ha}))(\mathrm{N}=10,770)$

\begin{tabular}{|c|c|c|c|c|}
\hline $\begin{array}{l}\text { Clusters of } \\
\text { agricultural } \\
\text { pesticides }\end{array}$ & $\begin{array}{c}\text { Women without } \\
\text { preeclampsia } \\
(\mathrm{n}=10,652) \\
\text { (exposed/unexposed women) } \\
\mathrm{n}(\%)\end{array}$ & $\begin{array}{l}\text { Women with preeclampsia } \\
(\mathrm{n}=118) \\
\text { (exposed/unexposed women) } \\
\mathrm{n}(\%)\end{array}$ & $\begin{array}{c}\text { Crude OR }{ }^{\mathrm{a}} \\
(95 \% \mathrm{CI})\end{array}$ & $\begin{array}{c}\text { Adjusted OR } \\
\quad(95 \% \mathrm{CI})\end{array}$ \\
\hline 1 & 4,231 (39.7)/6,421 (60.3) & $54(45.8) / 64(54.2)$ & $\begin{array}{c}1.64(1.09, \\
2.48)\end{array}$ & $\begin{array}{c}1.55(1.03, \\
2.34)\end{array}$ \\
\hline 2 & $2,667(25.0) / 7,985(75.0)$ & $26(22.0) / 92(78.0)$ & $\begin{array}{c}0.80(0.51 \\
1.27)\end{array}$ & $\begin{array}{c}0.84(0.53 \\
1.33)\end{array}$ \\
\hline 3 & $5,815(54.6) / 4,837(45.4)$ & $55(46.6) / 63(53.4)$ & $\begin{array}{c}0.62(0.41, \\
0.92)\end{array}$ & $\begin{array}{c}0.60(0.40 \\
0.90)\end{array}$ \\
\hline
\end{tabular}

Missing data about covariables were imputed as the mode or median value.

${ }_{a}$ The logistic regression was adjusted for the other clusters of pesticides shown in the table.

${ }_{b}$ The logistic regression was adjusted for food profiles, maternal age, BMI, smoking status, and educational level, and for the other pesticide clusters shown in the table.

Cluster 1: epoxiconazole, propiconazole, prochloraz, cyproconazole, tebuconazole, pyraclostrobin Cluster 2: diquat, 2,4-Dichlorophenoxyacetic acid

Cluster 3: cypermethrin, fenvalerate, chlorpyrifos, maneb, dimethoate, bifenthrin, fenoxycarb 
Table S14. Risk of preeclampsia associated with domestic pesticide use by hypertension treatment $(\mathrm{N}=13,533)$

\begin{tabular}{|c|c|c|c|c|}
\hline $\begin{array}{c}\text { Domestic exposure } \\
\mathrm{n}(\%)\end{array}$ & $\begin{array}{l}\text { Women without preeclampsia } \\
(\mathrm{n}=13,383) \\
\text { (exposed/unexposed women) } \\
\mathrm{n}(\%)\end{array}$ & $\begin{array}{l}\text { Women with preeclampsia } \\
(\mathrm{n}=150) \\
\text { (exposed/unexposed women) } \\
\mathrm{n}(\%)\end{array}$ & $\begin{array}{l}\text { Crude OR }{ }^{\mathrm{a}} \\
(95 \% \mathrm{CI})\end{array}$ & $\begin{array}{l}\text { Adjusted } \\
\text { OR }^{\mathrm{b}} \\
(95 \% \mathrm{CI})\end{array}$ \\
\hline $\begin{array}{l}\text { Use of pesticides against } \\
\text { crawling insects } \\
\text { - Hypertension not treated } \\
\text { - Treated hypertension }\end{array}$ & $2,082(15.5) / 11,341(84.5)$ & $\begin{array}{l}11(14.5) / 65(85.5) \\
18(26.1) / 51(73.9)\end{array}$ & $\begin{array}{c}0.80 \\
(0.41,1.55) \\
1.69 \\
(0.98,2.93)\end{array}$ & $\begin{array}{c}0.80 \\
(0.41,1.55) \\
1.65 \\
(0.95,2.87)\end{array}$ \\
\hline $\begin{array}{l}\text { Herbicide use } \\
\text { - Hypertension not treated } \\
\text { - Treated hypertension }\end{array}$ & $1,373(10.5) / 11,740(89.5)$ & $\begin{array}{c}4(5.5) / 69(94.5) \\
14(20.9) / 53(79.1)\end{array}$ & $\begin{array}{c}- \\
2.23 \\
(1.25,3.97)\end{array}$ & $\begin{array}{c}- \\
2.20 \\
(1.23,3.93)\end{array}$ \\
\hline $\begin{array}{l}\text { Flea collar use } \\
\text { - Hypertension not treated } \\
\text { - Treated hypertension }\end{array}$ & $328(2.5) / 12,584(97.5)$ & $\begin{array}{l}1(1.4) / 73(98.6) \\
1(1.5) / 67(98.5)\end{array}$ & & \\
\hline $\begin{array}{l}\text { Use of pesticides other than flea } \\
\text { collar against fleas and ticks } \\
\text { - Hypertension not treated } \\
\text { - Treated hypertension }\end{array}$ & $3,137(24.3) / 9,775$ (75.7) & $\begin{array}{l}18(24.3) / 56(75.7) \\
16(23.5) / 52(76.5)\end{array}$ & $\begin{array}{c}0.99 \\
(0.59,1.66) \\
0.91 \\
(0.53,1.59)\end{array}$ & $\begin{array}{c}0.92 \\
(0.55,1.55) \\
0.92 \\
(0.53,1.61)\end{array}$ \\
\hline $\begin{array}{l}\text { Fungicide use of outdoor plants } \\
\text { - Hypertension not treated } \\
\text { - Treated hypertension }\end{array}$ & $150(1.1) / 13,243(98.9)$ & $\begin{array}{l}2(2.6) / 74(97.4) \\
1(1.4) / 68(98.6)\end{array}$ & & \\
\hline
\end{tabular}

Missing values about covariables were imputed as the mode or median value.

${ }_{a}$ The logistic regression was adjusted for the other domestic pesticide uses shown in the table.

${ }_{b}$ The logistic regression was adjusted for maternal age, BMI, smoking status, and educational level and for the other domestic pesticide uses shown in the table. 
Table S15. Risk of preeclampsia associated with residential proximity to agricultural pesticide application by hypertension treatment $(\mathrm{N}=10,765)$

\begin{tabular}{|c|c|c|c|c|}
\hline $\begin{array}{c}\text { Agricultural exposure } \\
\mathrm{n}(\%)\end{array}$ & $\begin{array}{c}\text { Women without } \\
\text { preeclampsia } \\
(\mathrm{n}=10,652) \\
\text { (fourth quartile/first } 3 \\
\text { quartiles) } \\
\mathrm{n}(\%)\end{array}$ & $\begin{array}{l}\text { Women with preeclampsia } \\
\qquad(\mathrm{n}=113) \\
\text { (fourth quartile/first } 3 \\
\text { quartiles) } \\
\mathrm{n}(\%)\end{array}$ & $\begin{array}{l}\text { Crude OR }{ }^{\mathrm{a}} \\
(95 \% \mathrm{CI})\end{array}$ & $\begin{array}{l}\text { Adjusted } \mathrm{OR}^{\mathrm{b}} \\
\quad(95 \% \mathrm{CI})\end{array}$ \\
\hline $\begin{array}{l}\text { Cypermethrin } \\
\text { - Hypertension not treated } \\
\text { - Treated hypertension }\end{array}$ & $2,670(25.1) / 7,982(74.9)$ & $\begin{array}{l}13(22.0) / 46(78.0) \\
9(16.7) / 45(83.3)\end{array}$ & $\begin{array}{c}0.64 \\
(0.34,1.21) \\
0.54 \\
(0.26,1.12)\end{array}$ & $\begin{array}{c}0.63 \\
(0.33,1.20) \\
0.53 \\
(0.26,1.10)\end{array}$ \\
\hline $\begin{array}{l}\text { Prochloraz } \\
\text { - Hypertension not treated } \\
\text { - Treated hypertension }\end{array}$ & $2,656(24.9) / 7,996(75.1)$ & $\begin{array}{l}21(35.6) / 38(64.4) \\
14(25.9) / 40(74.1)\end{array}$ & $\begin{array}{c}1.96 \\
(1.13,3.39) \\
1.37 \\
(0.14,2.52)\end{array}$ & $\begin{array}{c}1.87 \\
(1.08,3.24) \\
1.28 \\
(0.70,2.37)\end{array}$ \\
\hline
\end{tabular}

Missing values about covariables were imputed as the mode or median value.

${ }_{a}$ The logistic regression was adjusted for the other pesticides shown in the table.

${ }_{b}$ The logistic regression was adjusted for maternal age, BMI, smoking status, and educational level and for the other pesticides shown in the table. 
Table S16. Risk of preeclampsia associated with dietary exposure to pesticides by hypertension treatment $(\mathrm{N}=13,555)$

\begin{tabular}{|c|c|c|c|c|}
\hline $\begin{array}{l}\text { Dietary pesticide } \\
\text { clusters } \\
\mathrm{n}(\%)\end{array}$ & $\begin{array}{c}\text { Women without } \\
\text { preeclampsia } \\
(\mathrm{n}=13,410) \\
\text { (exposed/unexposed women) } \\
\mathrm{n}(\%)\end{array}$ & $\begin{array}{l}\text { Women with preeclampsia } \\
(\mathrm{n}=155) \\
\text { (exposed/unexposed women) } \\
\mathrm{n}(\%)\end{array}$ & $\begin{array}{c}\text { Crude } \mathrm{OR}^{\mathrm{a}}(95 \% \\
\mathrm{CI})\end{array}$ & $\begin{array}{l}\text { Adjusted OR }{ }^{b} \\
\quad(95 \% \mathrm{CI})\end{array}$ \\
\hline $\begin{array}{l}\text { Cluster } 1 \\
\text { - } \text { Hypertension not } \\
\text { treated } \\
\text { - Treated hypertension }\end{array}$ & $4,022(30.0) / 9,388(70.0)$ & $\begin{array}{l}27(33.3) / 54(66.7) \\
11(14.9) / 63(85.1)\end{array}$ & $\begin{array}{c}1.42 \\
(0.90,2.23) \\
0.48 \\
(0.26,0.87)\end{array}$ & $\begin{array}{c}1.43 \\
(0.91,2.26) \\
0.49 \\
(0.27,0.90)\end{array}$ \\
\hline $\begin{array}{l}\text { Cluster } 2 \\
\text { - } \text { Hypertension not } \\
\text { treated } \\
\text { - } \text { Treated hypertension }\end{array}$ & $4,951(36.9) / 8,459(63.1)$ & $\begin{array}{l}18(22.2) / 63(77.8) \\
23(31.1) / 51(68.9)\end{array}$ & $\begin{array}{c}0.64 \\
(0.38,1.08) \\
0.95 \\
(0.58,1.57)\end{array}$ & $\begin{array}{c}0.71 \\
(0.42,1.21) \\
1.04 \\
(0.62,1.75)\end{array}$ \\
\hline $\begin{array}{l}\text { Cluster } 3 \\
\text { - Hypertension not } \\
\text { treated } \\
\text { - } \text { Treated hypertension }\end{array}$ & $3,398(25.3) / 10,012(74.7)$ & $\begin{array}{l}12(14.8) / 69(85.2) \\
12(16.2) / 62(83.8)\end{array}$ & $\begin{array}{c}0.73 \\
(0.40,1.32) \\
0.78 \\
(0.43,1.43)\end{array}$ & $\begin{array}{c}0.81 \\
(0.44,1.49) \\
0.85 \\
(0.46,1.58)\end{array}$ \\
\hline 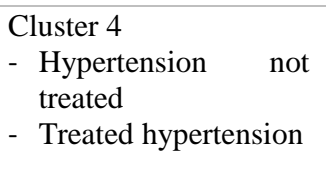 & $3,377(25.2) / 10,033(74.8)$ & $\begin{array}{l}19(23.5) / 6276.5) \\
13(17.6) / 61(82.4)\end{array}$ & $\begin{array}{c}1.15 \\
(0.69,1.89) \\
0.72 \\
(0.41,1.27)\end{array}$ & $\begin{array}{c}1.16 \\
(0.70,1.91) \\
0.72 \\
(0.40,1.27)\end{array}$ \\
\hline $\begin{array}{l}\text { Cluster } 5 \\
\text { - Hypertension not } \\
\text { treated } \\
\text { - } \text { Treated hypertension }\end{array}$ & $8,657(64.6) / 4,753(35.4)$ & $\begin{array}{l}41(50.6) / 40(49.4) \\
25(33.7) / 49(66.3)\end{array}$ & $\begin{array}{c}0.74 \\
(0.47,1.15) \\
1.62 \\
(0.99,2.66)\end{array}$ & $\begin{array}{c}0.74 \\
(0.48,1.16) \\
1.57 \\
(0.95,2.57)\end{array}$ \\
\hline $\begin{array}{l}\text { Cluster } 6 \\
\text { - Hypertension not } \\
\text { treated } \\
\text { - Treated hypertension }\end{array}$ & $4,555(34.0) / 8,855(66.0)$ & $\begin{array}{l}23(28.4) / 58(71.6) \\
22(29.7) / 52(70.3)\end{array}$ & $\begin{array}{c}0.83 \\
(0.51,1.37) \\
1.08 \\
(0.65,1.79)\end{array}$ & $\begin{array}{c}0.80 \\
(0.49,1.31) \\
1.04 \\
(0.63,1.72)\end{array}$ \\
\hline $\begin{array}{l}\text { Cluster } 7 \\
\text { - } \text { Hypertension not } \\
\text { treated } \\
\text { - Treated hypertension }\end{array}$ & $9,200(68.6) / 4,210(31.4)$ & $\begin{array}{c}44(54.3) / 37(45.7) \\
37(50) / 37(50)\end{array}$ & $\begin{array}{c}0.93 \\
(0.58,1.48) \\
0.56 \\
(0.34,0.91)\end{array}$ & $\begin{array}{c}1.0 \\
(0.62,1.59) \\
0.60 \\
(0.37,0.98)\end{array}$ \\
\hline
\end{tabular}

Missing values about covariables were imputed as the mode or median value.

${ }_{a}$ The logistic regression was adjusted for the other diet pesticides clusters shown in the table.

${ }_{b}$ The logistic regression was adjusted for maternal age, BMI, smoking status, and educational level and for the other diet pesticides clusters shown in the table. 
Table S17. Risk of gestational hypertension associated with domestic pesticide use $(\mathrm{N}=17,461)$

\begin{tabular}{|l|c|c|c|c|c|}
\hline $\begin{array}{l}\text { Domestic } \\
\text { pesticide use } \\
\mathrm{n}(\%)\end{array}$ & $\begin{array}{c}\text { Missing } \\
\text { data }\end{array}$ & $\begin{array}{c}\text { Women without gestational } \\
\text { hypertension } \\
(\mathrm{n}=17,181)\end{array}$ & $\begin{array}{c}\text { Women with gestational } \\
\text { hypertension } \\
(\mathrm{n}=280)\end{array}$ & $\begin{array}{c}\text { Crude OR } \\
(95 \% \mathrm{CI})\end{array}$ & $\begin{array}{c}\text { Adjusted } \\
\text { OR }^{\mathrm{b}}\end{array}$ \\
$(95 \% \mathrm{CI})$
\end{tabular}

Missing data about covariables were imputed as the mode or median value.

${ }_{a}$ The logistic regression was adjusted for the other domestic pesticide uses shown in the table.

${ }_{b}$ The logistic regression was adjusted for maternal age, BMI, smoking status, and educational level and for the other domestic pesticide uses shown in the table. 
Table S18. Risk of gestational hypertension associated with dietary pesticide exposure $(\mathrm{N}=10,317)$

\begin{tabular}{|c|c|c|c|c|}
\hline $\begin{array}{c}\text { Dietary } \\
\text { pesticide } \\
\text { clusters } \\
\mathrm{n}(\%)\end{array}$ & $\begin{array}{c}\text { Women without gestational } \\
\text { hypertension } \\
(\mathrm{n}=10,130)\end{array}$ & $\begin{array}{c}\text { Women with gestational } \\
\text { hypertension } \\
(\mathrm{n}=187)\end{array}$ & $\begin{array}{c}\text { Crude OR } \\
(95 \% \mathrm{CI})\end{array}$ & $\begin{array}{c}\text { Adjusted OR }^{\mathrm{b}} \\
(95 \% \mathrm{CI})\end{array}$ \\
\hline 1 & $\begin{array}{c}\text { (exposed/unexposed women) } \\
\mathrm{n}(\%)\end{array}$ & $\begin{array}{c}\text { (exposed/unexposed women) } \\
\mathrm{n}(\%)\end{array}$ & \\
\hline 2 & $3,194(31.5) / 6,936(68.5)$ & $64(34.2) / 123(65.8)$ & $1.19(0.87,1.62)$ & $1.19(0.87,1.62)$ \\
\hline 3 & $2,291(22.6) / 7,839(77.4)$ & $29(15.5) / 158(84.5)$ & $0.67(0.44,1.01)$ & $0.69(0.45,1.05)$ \\
\hline 4 & $2,298(22.7) / 7,832(77.3)$ & $41(21.9) / 146(78.1)$ & $0.99(0.70,1.42)$ & $0.69(0.45,1.05)$ \\
\hline 5 & $5,900(58.2) / 4,230(41.8)$ & $96(51.3) / 91(48.7)$ & $0.78(0.58,1.06)$ & $0.78(0.57,1.06)$ \\
\hline 6 & $3,174(31.3) / 6,956(68.7)$ & $53(28.3) / 134(71.7)$ & $0.90(0.65,1.26)$ & $0.85(0.61,1.19)$ \\
\hline 7 & $6,244(61.6) / 3,886(38.4)$ & $105(56.1) / 82(43.9)$ & $0.89(0.65,1.23)$ & $0.92(0.67,1.27)$ \\
\hline
\end{tabular}

Missing data about covariables were imputed as the mode or median value.

${ }_{a}$ The logistic regression was adjusted for the other clusters of pesticide shown in the table.

${ }_{b}$ The logistic regression was adjusted for food profiles, maternal age, BMI, smoking status, and educational level and for the other pesticide clusters shown in the table.

Cluster 1: cyproconazole, fenoxycarb, dimetomorph, propiconazole, bioallethrin, fipronil, flusilazole, pentachlorophenol, paraquat, diuron, alachlor

Cluster 2: endosulfan, fenvalerate, bifenthrin

Cluster 3: dieldrin, DDT (Dichlorodiphenyltrichloroethane)

Cluster 4: vinclozolin

Cluster 5: carbofuran, atrazine, cypermethrin, chlordecone

Cluster 6: hexachlorophenol, diazinon

Cluster 7: epiconazole, malathion, chlorpyrifos, dimethoate, procymidone, tebuconazole 
Table S19. Ridge regression ${ }^{\mathrm{a}}$ result for association between gestational hypertension and residential proximity to agricultural pesticide application ${ }^{\mathrm{b}}$

\begin{tabular}{|l|c|c|}
\hline Residential proximity to agricultural application & $\beta$ & $p$-value \\
\hline Tebuconazole & $-1.04 \times 10^{-3}$ & 0.51 \\
\hline Fenvalerate & $-1.94 \times 10^{-3}$ & 0.23 \\
\hline Cypermethrin & $3.05 \times 10^{-4}$ & 0.60 \\
\hline Chlorpyrifos & $-8.40 \times 10^{-4}$ & 0.48 \\
\hline Dimethoate & $-1.18 \times 10^{-3}$ & 0.85 \\
\hline Pyraclostrobin & $-3.08 \times 10^{-4}$ & 0.74 \\
\hline Cyproconazole & $-5.28 \times 10^{-4}$ & 0.71 \\
\hline Epoxyconazole & $-5.84 \times 10^{-4}$ & 0.99 \\
\hline Propiconazole & $-1.32 \times 10^{-5}$ & 0.23 \\
\hline 2,4-dichlorophenoxyacetic acid (2,4 D) & $-1.94 \times 10^{-3}$ & 0.79 \\
\hline Bifenthrin & $1.58 \times 10^{-3}$ & 0.26 \\
\hline Diquat & $-1.84 \times 10^{-3}$ & 0.70 \\
\hline Fenoxycarb & $8.22 \times 10^{-4}$ & 0.96 \\
\hline Maneb & $1.02 \times 10^{-4}$ & 0.75 \\
\hline Prochloraz & $-5.09 \times 10^{-4}$ & \\
\hline Missing & & \\
\hline
\end{tabular}

Missing data about covariables were imputed as the mode or the median value.

${ }^{a}$ Ridge regression was adjusted for maternal age, BMI, maternal status and educational level. The penalized parameter $\lambda$ was determined by 10-fold cross-validation $(\lambda=0.8093881)$

${ }^{b}$ Agricultural pesticide drift was estimated by using a 1000-m radius around women's homes (kg/ha). Exposure was a binary variable (the three first quartiles versus the fourth). 
Figure S1. Directed acyclic graph representing the causal assumptions used for covariate selection The DAG was created with DAGitty version 2.3 (http://dagitty.net/).

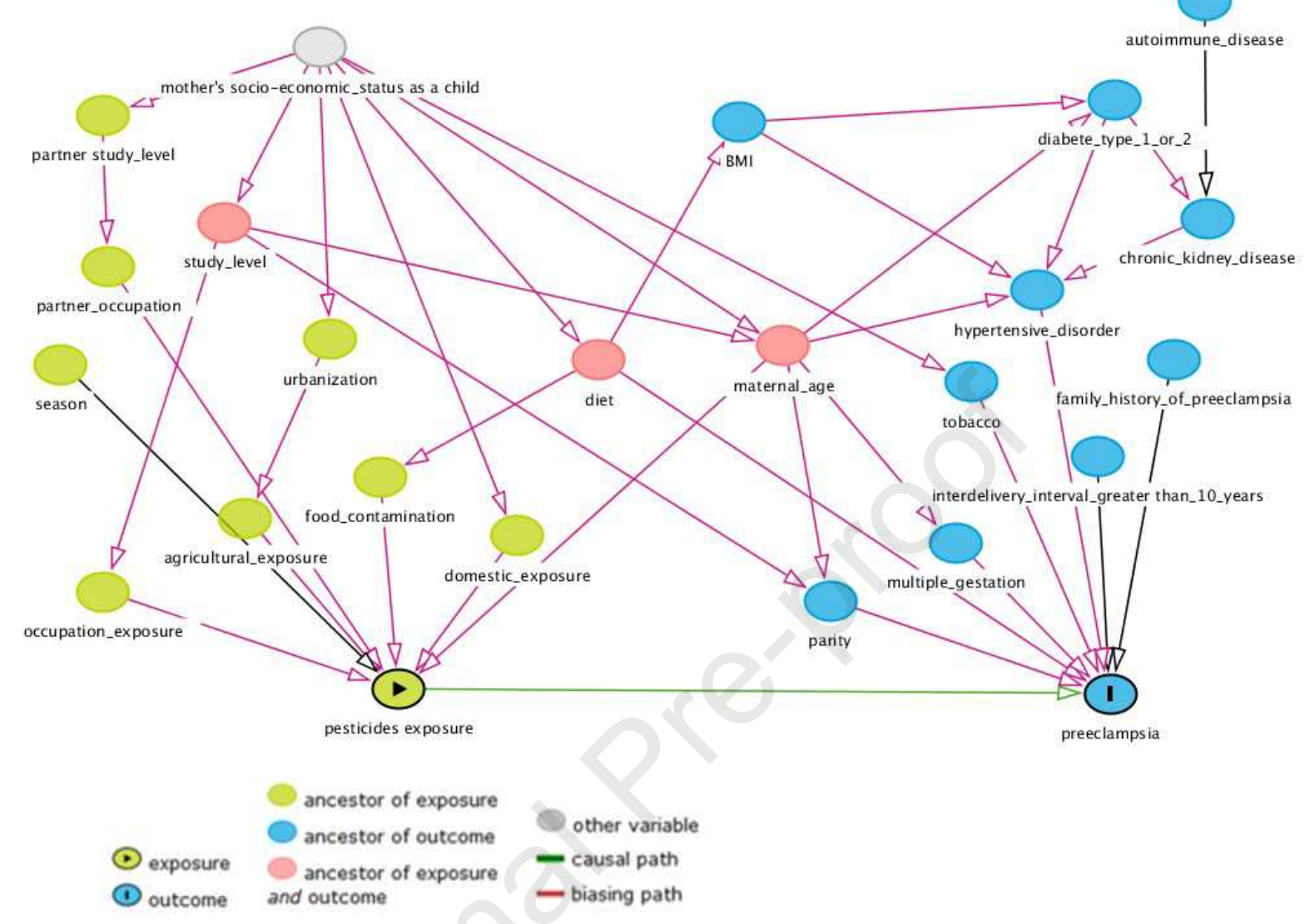


Figure S2. Flow chart for the gestational hypertension population study

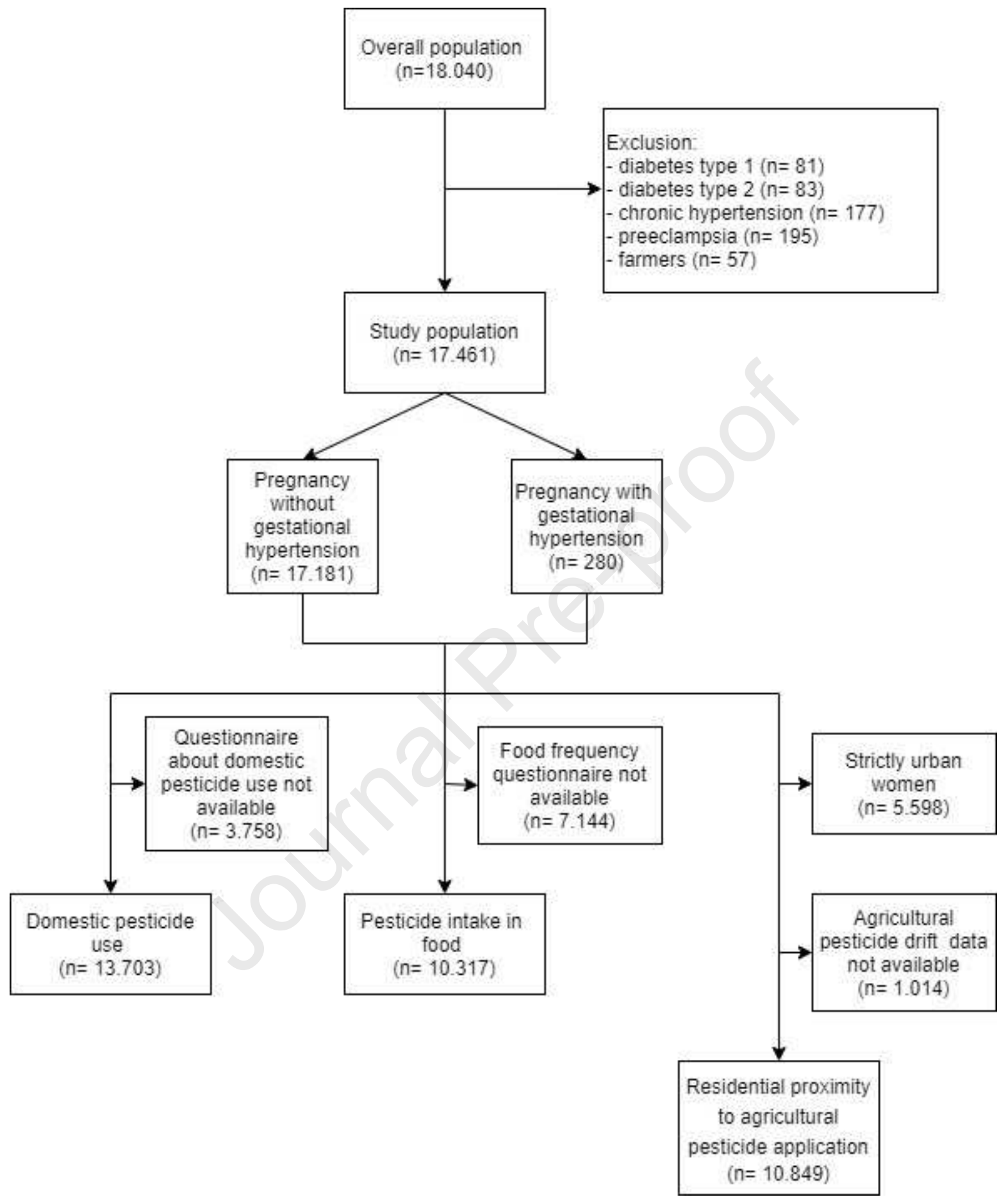


Figure S3. Agricultural pesticides allocated into clusters by multiple correspondence analysis and hierarchical ascending classification

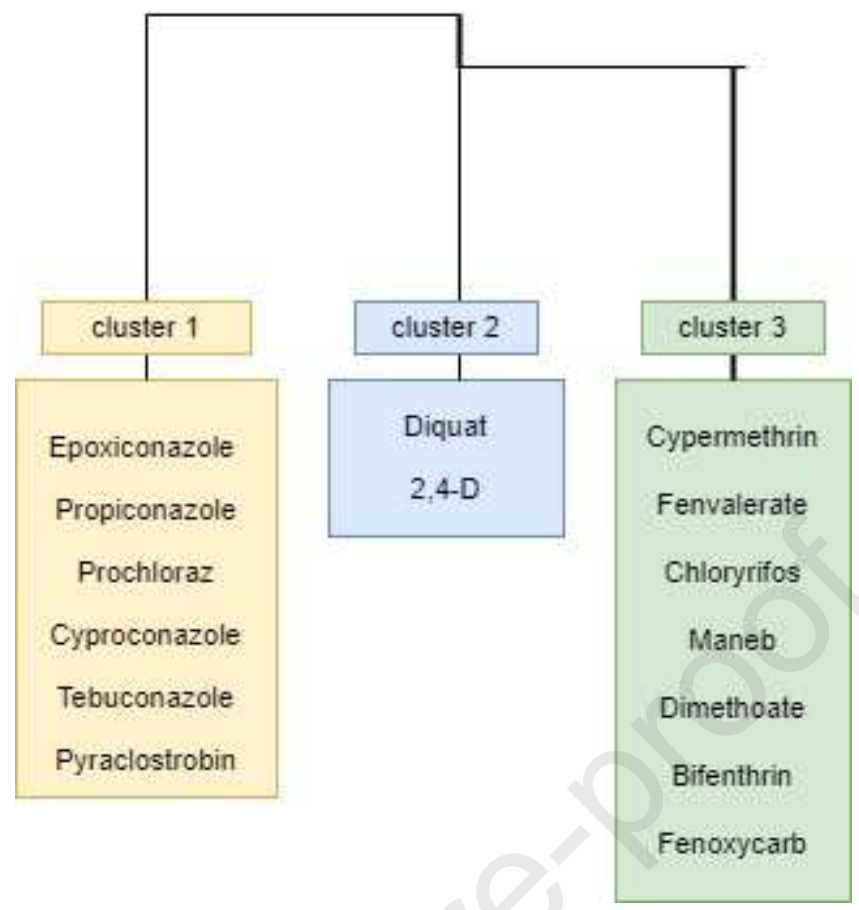

2,4-D: 2,4-Dichlorophenoxyacetic acid 
- Pesticides selected by a toxicogenomic approach.

- Study of three sources of pesticide exposure.

- Women with preeclampsia were more often exposed to prochloraz. 


\section{Declaration of interests}

$\bigotimes$ The authors declare that they have no known competing financial interests or personal relationships that could have appeared to influence the work reported in this paper.

$\square$ The authors declare the following financial interests/personal relationships which may be considered as potential competing interests: 